TITLE:

\title{
Physicochemical properties and plastic crystal structures of phosphonium fluorohydrogenate salts.
}

\section{AUTHOR(S):}

Enomoto, Takeshi; Kanematsu, Shunsuke;

Tsunashima, Katsuhiko; Matsumoto, Kazuhiko; Hagiwara, Rika

\section{CITATION:}

Enomoto, Takeshi ...[et al]. Physicochemical properties and plastic crystal structures of phosphonium fluorohydrogenate salts.. Physical chemistry chemical physics: PCCP 2011, 13(27): 12536-12544

\section{ISSUE DATE:}

2011-07-21

URL:

http://hdl.handle.net/2433/156866

RIGHT:

(c) The Owner Societies 2011.; この論文は出版社版でありません。引用 の際には出版社版をご確認ご利用ください。; This is not the published version. Please cite only the published version. 


\section{Physicochemical properties and plastic crystal structures of phosphonium fluorohydrogenate salts}

Takeshi Enomoto, ${ }^{a}$ Shunsuke Kanematsu, ${ }^{a}$ Katsuhiko Tsunashima,${ }^{b}$ Kazuhiko Matsumoto, ${ }^{* a}$ Rika Hagiwara $^{a}$

${ }^{a}$ Graduate School of Energy Science, Kyoto University, Yoshida, Sakyo-ku, Kyoto 606-8501, Japan

${ }^{b}$ Department of Materials Science, Wakayama National College of Technology, 77 Nada-cho, Noshima, Gobo 644-0023, Japan

*E-mail: k-matsumoto@energy.kyoto-u.ac.jp

$\dagger$ Electronic supplementary information (ESI) available: Calculated geometrical parameters, volumes, and vibrational frequencies, X-ray powder diffraction data, DSC curves, viscosities, conductivities, elemental analyses, and IR spectra. See DOI: 10.1039/c1cp20285e. 


\section{Table of Contents entry}

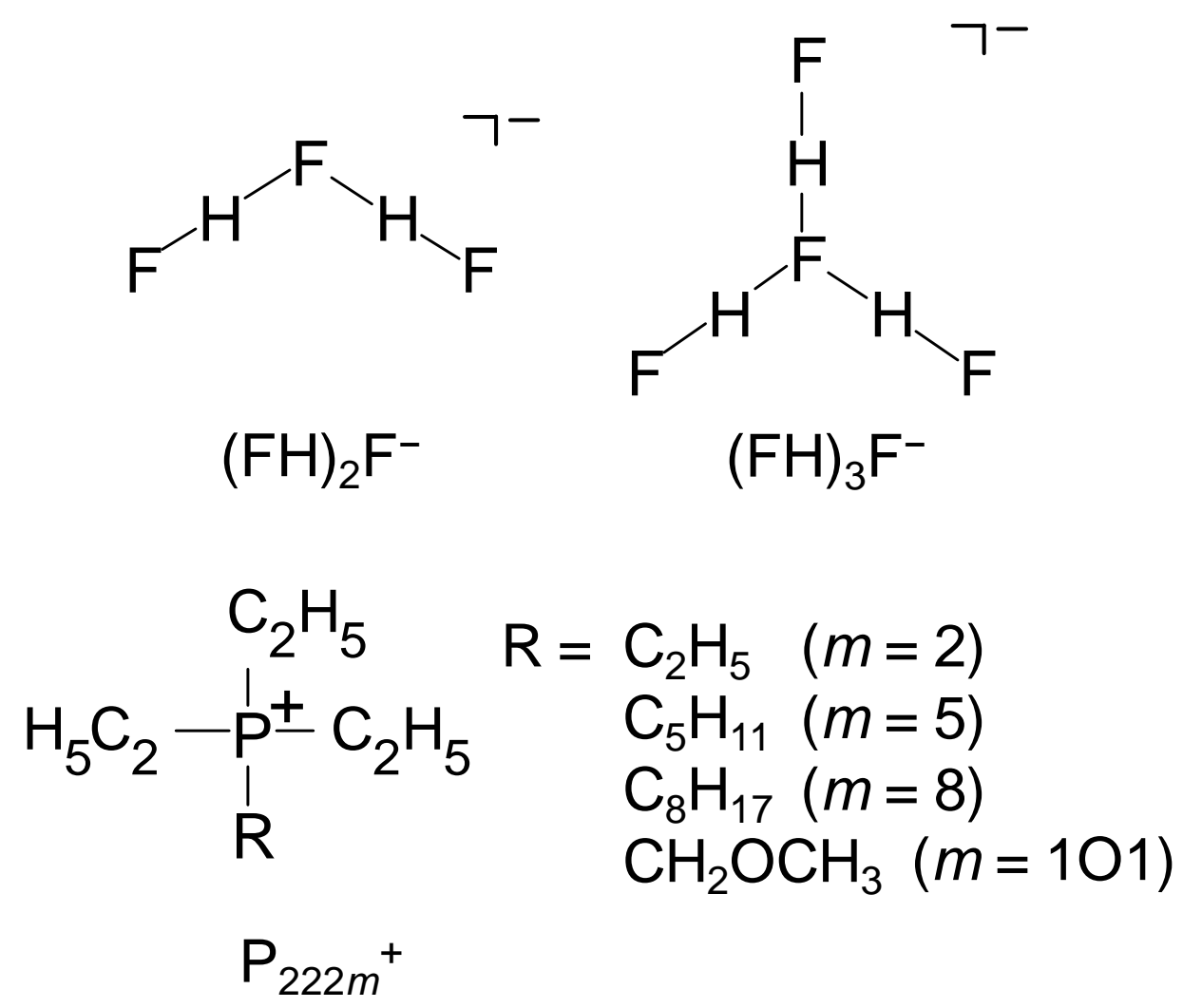

Fluorohydrogenate salts based on quaternary phosphonium cations with short alkyl and methoxy groups form room temperature ionic liquids or ionic plastic crystals with high conductivities. 


\section{Abstract}

Fluorohydrogenate salts of quaternary phosphonium cations with short alkyl and methoxy groups (tetraethylphosphonium $\left(\mathrm{P}_{2222}{ }^{+}\right)$, triethyl- $n$-pentylphosphonium $\left(\mathrm{P}_{2225}{ }^{+}\right)$, triethyl- $n$-octylphosphonium $\left(\mathrm{P}_{2228}{ }^{+}\right)$, and triethylmethoxymethylphosphonium $\left.\left(\mathrm{P}_{222(1 \mathrm{O} 1)}{ }^{+}\right)\right)$have been synthesized by the metatheses of anhydrous hydrogen fluoride and the corresponding phosphonium bromide or chloride precursors. The three salts with asymmetric cations, $\mathrm{P}_{222 m}(\mathrm{FH})_{2.1} \mathrm{~F}(m=5,8$, and 1O1), are room temperature ionic liquids (ILs) and characterized by differential scanning calorimetry, density, viscosity, and conductivity measurements. Linear sweep voltammetry using a glassy carbon working electrode shows these phosphonium fluorohydrogenate ILs have wide electrochemical windows $(>4.9 \mathrm{~V})$ with the lowest viscosity and highest conductivity in the known phosphonium-based ILs. Thermogravimetry shows their thermal stabilities are also improved compared to previously reported alkylammonium cation-based fluorohydrogenate salts. Differential scanning calorimetry and X-ray diffraction revealed that tetraethylphosphonium fluorohydrogenate salt, $\mathrm{P}_{2222}(\mathrm{FH})_{2} \mathrm{~F}$, exhibits two plastic crystal phases. The high temperature phase has a hexagonal lattice, which is the first example of a plastic crystal phase with an inverse nickel arsenide-type structure, and the low-temperature phase has an orthorhombic lattice. The high-temperature plastic crystal phase exhibits a conductivity of $5 \mathrm{mS} \mathrm{cm}^{-1}$ at $50^{\circ} \mathrm{C}$, which is the highest value for the neat plastic crystals. 


\section{Introduction}

Ionic liquids (ILs) composed of alkylammonium cations and various chloro- or fluoroanions have attracted much attention and have been extensively investigated because of their unique properties. ${ }^{1-13}$

Characteristic features often found for ILs are extremely low vapor pressure, non-flammability, high thermal and electrochemical stabilities, and wide temperature range of liquid phase around room temperature. ${ }^{1-13}$ Their potential applications include electrolytes in batteries, electrochemical capacitors, and electrolytic bath and environmentally benign media for synthetic and catalytic reactions as well as extraction. ${ }^{1-9,14,15}$ However, the high viscosity and low conductivity of ILs prevent them from some applications such as the use as electrolyte in electrochemical devices. ${ }^{7,8}$

Researches on phosphonium-based ILs have been increasing in terms of applications as electrolytes in electrochemical devices owing to their high thermal and electrochemical stabilities compared to previously known ammonium-based ILs such as alkyl-ammonium, imidazolium, pyridinium, pyrrolidinium, and piperidinium. High thermal and electrochemical stabilities are important factors to improve safety, durability, and power and energy densities of electrochemical devices such as electric double layer capacitors. ${ }^{16-19}$ Furthermore, some phosphonium ILs exhibit lower viscosity and higher conductivity than the corresponding ammonium ILs. ${ }^{18}$

Some of the organic salts which form ILs exhibit mesophases such as liquid crystal or plastic crystal phases around room temperature as in the cases of molecular substances. ${ }^{20-30}$ Ionic liquid crystals have anisotropic structures and are potential materials as anisotropic ion-conduction materials as well as anisotropic reaction media. ${ }^{20-27}$ Ionic plastic crystals contain ionic species rotating three-dimensionally. 
Such rotation produces an expanded lattice usually with a simple crystal structure and fast ion conduction, which makes plastic crystals as potential electrolytes with no leakage, high electrochemical stability, and non-flammability. ${ }^{30-36}$ The plastic crystal phase of succinonitrile is studied as solid electrolyte matrix of batteries, dye-sensitized solar cells, and fuel cells. ${ }^{37-41}$ The applications of plasticpolymer composite electrolytes which are the mixture of lithium salts and plastic crystalline succinonitrile including polymer are also studied, ${ }^{42-44}$ and the ionic conductivity of the electrolytes is affected by solvent dynamics and ion association. ${ }^{44-46}$

Fluorohydrogenate ILs contain fluorohydrogenate anions $\left((\mathrm{FH})_{n} \mathrm{~F}^{-}\right.$) (Figure 1) and exhibit low viscosity and high conductivity ${ }^{19,27,47-53}$ (e.g. $4.9 \mathrm{cP}$ and $100 \mathrm{mS} \mathrm{cm}^{-1}$ at $25^{\circ} \mathrm{C}$ for 1-ethyl-3methylimidazolium fluorohydrogenate $\left.\left(\operatorname{EMIm}(\mathrm{FH})_{2.3} \mathrm{~F}\right)^{19}\right)$, which are derived from the weakened cation-anion interaction through HF exchange. ${ }^{54}$ Because of such unique properties, fluorohydrogenate ILs are attractive candidates as electrolytes in fuel cells and electric double layer capacitors. ${ }^{7,12,55,56}$ The composition ' $n$ ' of the vacuum-stable fluorohydrogenate ILs depends on the temperature of evacuation and is 2.3 at $25^{\circ} \mathrm{C}$ (the abundance ratio of $(\mathrm{FH})_{2} \mathrm{~F}^{-}$to $(\mathrm{FH})_{3} \mathrm{~F}^{-}$is $7: 3$ from its composition) in most cases regardless of the cationic structures including imidazolium, pyridinium, pyrrolidinium, piperidinium, and previously reported phosphonium cations. ${ }^{19,47-53}$ According to a previous report, incorporation of tetraalkylphosphonium cations with fluorohydrogenate anions give ILs with high electrochemical and thermal stabilities although they still have high viscosity and low conductivity among the previously reported fluorohydrogenate ILs with alkylammonium cations. ${ }^{53}$ For example, tri- $n$ - 
butylmethylphosphonium fluorohydrogenate IL, $\mathrm{P}_{4441}(\mathrm{FH})_{2.3} \mathrm{~F}$, exhibits a viscosity of $36 \mathrm{cP}$, conductivity of $6 \mathrm{mS} \mathrm{cm}^{-1}$, and electrochemical window of $6.0 \mathrm{~V}^{53}$

In this study, fluorohydrogenate ILs with four quaternary phosphonium cations, tetraethylphosphonium $\left(\mathrm{P}_{2222}{ }^{+}\right)$, triethyl-n-pentylphosphonium $\left(\mathrm{P}_{2225}{ }^{+}\right)$, triethyl-n-octylphosphonium $\left(\mathrm{P}_{2228}{ }^{+}\right)$, and triethylmethoxymethylphosphonium $\left(\mathrm{P}_{222(1 \mathrm{O} 1)^{+}}\right)$cations (see Figure 1), are prepared and their physical, structural, and electrochemical properties are discussed.

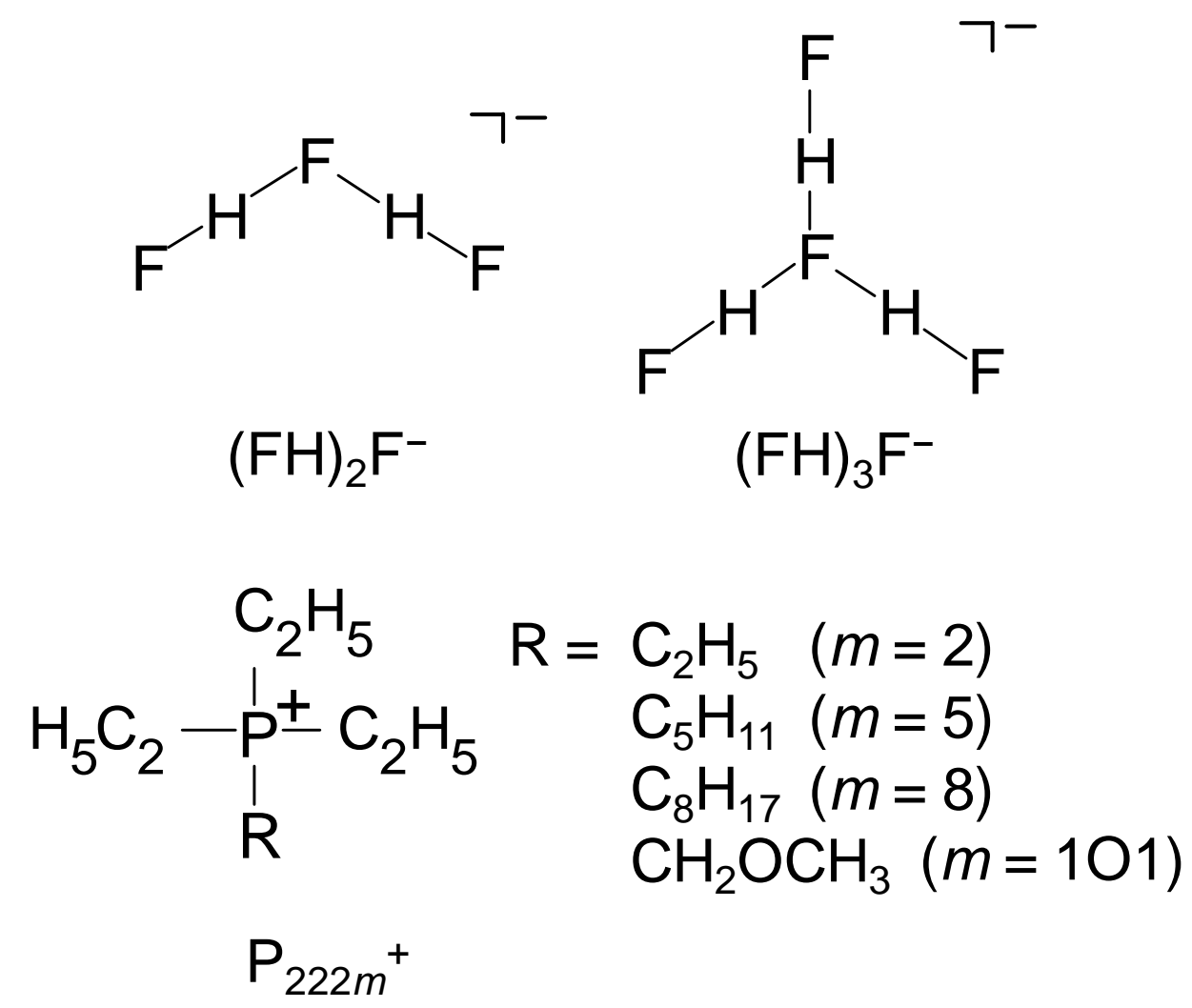

Figure 1. Fluorohydrogenate anions, $(\mathrm{FH})_{n} \mathrm{~F}^{-}\left(n=1,2\right.$, and 3), and phosphonium cations, $\mathrm{P}_{222 m}{ }^{+}(m=2$, 5,8 , and 101). 


\section{Experimental}

Caution: Handling of anhydrous HF must be carefully performed using appropriate protective gear with immediate access to proper treatment procedures in the accident of contact with liquid HF, HF vapor, or HF-containing compounds. ${ }^{57}$

Apparatus and Materials. Moisture sensitive materials were handled in a glove box. A vacuum line was constructed of stainless steel to handle corrosive gases. The line was connected to a rotary vacuum pump through a soda lime chemical trap connected to a glass cold trap in series. The tetrafluoroethylene-perfluoroalkylvinylether copolymer (PFA) reactor connected to a stainless steel valve with a Kel-F tip was used as a reaction vessel. Anhydrous hydrogen fluoride, aHF (Stella Chemifa Corp., purity 99.9\%), was dried over $\mathrm{K}_{2} \mathrm{NiF}_{6}$ (Ozark-Mahoning Co.) for several days prior to use. The quaternary phosphonium precursors, $\mathrm{P}_{2222} \mathrm{Br}, \mathrm{P}_{2225} \mathrm{Br}, \mathrm{P}_{2228} \mathrm{Br}$, and $\mathrm{P}_{222(101)} \mathrm{Cl}$, provided by Nippon Chemical Industry Co. Ltd. were dried under vacuum above $80^{\circ} \mathrm{C}$ for more than one day prior to use.

Synthesis. Fluorohydrogenate ILs were prepared by the reaction of a large excess of aHF and $\mathrm{P}_{2222} \mathrm{Br}$, $\mathrm{P}_{2225} \mathrm{Br}, \mathrm{P}_{2228} \mathrm{Br}$, or $\mathrm{P}_{222(101)} \mathrm{Cl}$ according to the literature method. ${ }^{19,49}$ The precursor was weighed and loaded in a PFA reactor under a dry argon atmosphere, followed by reaction with a large excess of aHF at room temperature. Addition of fresh aHF and elimination of volatile gases were repeated several times to eliminate $\mathrm{Br}^{-}$or $\mathrm{Cl}^{-}{ }^{19,49}$ Because of the difficulty in removal of $\mathrm{HBr}$ compared to the case of $\mathrm{HCl}$, the reaction with the bromide precursors required more $\mathrm{HF}$ than the case of the reaction with the chloride precursors. Elimination of the volatile gases at $25^{\circ} \mathrm{C}$ gave room temperature ILs of $\mathrm{P}_{222 m}(\mathrm{FH})_{2.1} \mathrm{~F}\left(m=5,8\right.$, and 1O1) and a solid of $\mathrm{P}_{2222}(\mathrm{FH})_{2.2} \mathrm{~F}$. The salt, $\mathrm{P}_{2222}(\mathrm{FH})_{2} \mathrm{~F}$, was prepared by 
stoichiometrically mixing $\mathrm{P}_{2222}(\mathrm{FH})_{2.2} \mathrm{~F}$ with the HF-deficient salt $\mathrm{P}_{2222}(\mathrm{FH})_{1.9} \mathrm{~F}$ which was prepared by evacuating $\mathrm{P}_{2222}(\mathrm{FH})_{2.2} \mathrm{~F}$ at $100^{\circ} \mathrm{C}{ }^{49}$ The samples, $\mathrm{P}_{222 m}(\mathrm{FH})_{2.1} \mathrm{~F}(m=2,5,8$, and $1 \mathrm{O} 1)$, showed no $\mathrm{AgBr}$ or $\mathrm{AgCl}$ precipitation after adding aqueous $\mathrm{AgNO}_{3}$ and were identified by elemental analyses and infrared (IR) spectra (see Table S1, ESI $\uparrow$ for the results of elemental analysis and Figure S1 for IR spectra).

Analysis. Phase transition temperatures were determined by a differential scanning calorimeter, DSC60 (Shimadzu Corp.) under a dry argon gas flow $\left(50 \mathrm{~mL} \mathrm{~min}^{-1}\right)$. Samples were sealed in stainless steel cells using a high-pressure sealing machine in a glove box. The atmosphere around the cell was purged with dry argon gas during the measurement. A scan rate of $5^{\circ} \mathrm{C} \min ^{-1}$ was used for all the experiments, whereas $1^{\circ} \mathrm{C} \min ^{-1}$ was occasionally used for precise analysis of $\mathrm{P}_{2222}(\mathrm{FH})_{2} \mathrm{~F}$. Thermal decomposition temperatures for $\mathrm{P}_{222 m}(\mathrm{FH})_{2.1} \mathrm{~F}(m=5,8$, and 101) were measured by a thermogravimetric analyzer, DTG-60H (Shimadzu Corp.) under a dry argon gas flow $\left(50 \mathrm{~mL} \mathrm{~min}{ }^{-1}\right)$. Platinum cells used for the measurement were washed with acetone just before the measurement and dried in the apparatus at $200^{\circ} \mathrm{C}$ for 10 minutes. The temperature was scanned from room temperature to $400^{\circ} \mathrm{C}$ with a heating rate of $10^{\circ} \mathrm{C} \mathrm{min}^{-1}$. Viscosities were measured by a cone and plate rheometer, LVDV-II+PRO (Brookfield Engineering Laboratories, Inc.) with a CPE-40 spindle. Conductivity measurements were performed with the aid of PARSTAT 2273 (Princeton Applied Research) or VSP (Bio-Logic) electrochemical measurement system. Conductivity was measured by an AC impedance technique using a cell with platinum disk electrodes calibrated using $\mathrm{KCl}$ standard aqueous solutions. The sample, $\mathrm{P}_{2222}(\mathrm{FH})_{2} \mathrm{~F}$, was held at each temperature for 2.5 hours. Density was measured by weighing the sample 
in a calibrated PFA vessel. Electrochemical stability was investigated by linear sweep voltammetry under a dry argon atmosphere with the aid of HZ-3000 (Hokuto Denko Corp.) electrochemical measurement system. Glassy carbon electrodes (Tokai Carbon Co., Ltd.) with a surface area of $0.07 \mathrm{~cm}^{2}$ and $0.20 \mathrm{~cm}^{2}$ were used for the working and counter electrodes, respectively. A silver wire (Japan metal service, $1.0 \mathrm{~mm} \phi$, purity $99.99 \%$ ) immersed in $\mathrm{EMlmBF}_{4}$ containing $0.05 \mathrm{M} \mathrm{AgBF}_{4}$ was used for the reference electrode and was partitioned in the electrolyte with a porous polytetrafluoroethylene (PTFE) filter. A platinum plate (Nilaco Corp., $0.1 \mathrm{~mm}$ thickness) with a surface area of $0.15 \mathrm{~cm}^{2}$ was also used for the working electrode. The obtained potentials were referenced to the redox potential of ferrocenium/ferrocene $\left(\mathrm{Fc}^{+} / \mathrm{Fc}\right)$ couple. Residual water contents in the samples were measured by Karl Fischer moisture titrator, MKC-510N (Kyoto Electronics Manufacturing Co., Ltd.). Infra-red spectra were obtained by an FT-IR spectrometer, FTS-155 (Bio-Rad Laboratories, Inc.). The sample was sandwiched between a pair of $\mathrm{AgCl}$ windows fixed in a stainless airtight cell.

X-Ray Powder Diffraction Analysis. Capillaries used for X-ray diffraction measurements were dried under vacuum at $500^{\circ} \mathrm{C}$. The plastic samples of $\mathrm{P}_{2222}(\mathrm{FH})_{2} \mathrm{~F}$ were transferred into a quartz capillary (Overseas X-Ray Service Co., Ltd.) in a glove box. The capillary was temporarily plugged with silicone grease, and then flame-sealed outside the glove box using an oxygen microburner. The sample was centered on an X-ray diffractometer, R-AXIS RAPID-II (Rigaku Corp.), equipped with an imaging plate area detector and graphite-monochromated MoK $\alpha$ radiation $(\lambda=0.71073 \AA)$. The RAPID XRD 2.3.3 $3^{58}$ was used to control the diffractometer and the $\phi$ angle was rotated at a rate of $1^{\circ} \mathrm{s}^{-1}$ during data 
collection $(720 \mathrm{~s})$. The temperature of the sample was controlled by dry nitrogen flow. The XRD patterns of $\mathrm{P}_{2222}(\mathrm{FH})_{2} \mathrm{~F}$ were indexed with the aid of the DICVOL04 ${ }^{59}$.

Quantum Mechanical Calculation. The Gaussian 03 program $^{60}$ was used for quantum mechanical calculations. The optimized geometries, volumes, and vibrational data of $\mathrm{P}_{2222}{ }^{+}$were calculated at $\mathrm{HF}$, B3LYP, PBE1PBE, MPW1PW91, and MP2 levels of theory using cc-pVTZ basis set.

\section{Results and discussion}

Properties of $P_{222 m}(\mathbf{F H})_{2.1} \mathbf{F}(m=5,8$, and 101). The vacuum-stable salt obtained by the reaction of $\mathrm{P}_{2225} \mathrm{Br}, \mathrm{P}_{2228} \mathrm{Br}$, or $\mathrm{P}_{222(101)} \mathrm{Cl}$ and anhydrous $\mathrm{HF}$ is a colorless IL with the $\mathrm{HF}$ composition formulated as $\mathrm{P}_{222 m}(\mathrm{FH})_{2.1} \mathrm{~F}(m=5,8$, and $1 \mathrm{O} 1)$ at room temperature. The water content in these samples was below $100 \mathrm{ppm}$ according to the Karl-Fischer titration. The vacuum-stable HF composition in the anion (n) for $\mathrm{P}_{222 m}(\mathrm{FH})_{2.1} \mathrm{~F}$ is different from 2.3 observed for previously known fluorohydrogenate ILs based on $N$-heterocyclic ammonium cations $s^{19,47-52}$ and phosphonium cations with long alkyl chains ${ }^{53}$. The difference in the cationic structures changes the cation-anion interaction, resulting in the change in vacuum-stable composition. Other cases which give the $n$ value smaller than 2.3 are 1-alkyl-3methylimidazolium fluorohydrogenate with long alkyl side-chains ${ }^{27}$, where introduction of long alkyl side-chains enhances formation of liquid-crystalline behavior and changes the cation-anion interactions.

Differential scanning calorimetric (DSC) curves for the $\mathrm{P}_{222 m}(\mathrm{FH})_{2.1} \mathrm{~F}$ salts are shown in Figure 2. Thermal behavior of these salts are explained by analogy with the phase diagrams of EMIm( $\mathrm{FH}{ }_{n} \mathrm{~F}$ and $\mathrm{M}(\mathrm{FH})_{n} \mathrm{~F}(\mathrm{M}=$ alkali metals $) .{ }^{49,61,62}$ Melting of $\mathrm{P}_{222 m}(\mathrm{FH})_{2} \mathrm{Fs}$ and $\mathrm{P}_{222 m}(\mathrm{FH})_{3} \mathrm{Fs}$ are observed separately 
for these three salts, the latter melting from the mixture of crystal phases to the eutectic liquid. For $\mathrm{P}_{2225}(\mathrm{FH})_{2.1} \mathrm{~F}$, crystallization and melting $\left(-55^{\circ} \mathrm{C}\right)$ of only $\mathrm{P}_{2225}(\mathrm{FH})_{2} \mathrm{~F}$ are observed after the glass transition $\left(-107^{\circ} \mathrm{C}\right)$ in the heating process. For $\mathrm{P}_{2228}(\mathrm{FH})_{2.1} \mathrm{~F}$, the peak assigned to the simultaneous crystallization of $\mathrm{P}_{2228}(\mathrm{FH})_{2} \mathrm{~F}$ and $\mathrm{P}_{2228}(\mathrm{FH})_{3} \mathrm{~F}$ is observed in the cooling process. During the heating process, the $\mathrm{P}_{2228}(\mathrm{FH})_{3} \mathrm{~F}$ domain melts at $-46^{\circ} \mathrm{C}$, followed by melting of the $\mathrm{P}_{2228}(\mathrm{FH})_{2} \mathrm{~F}$ domain at $-27^{\circ} \mathrm{C}$. In the cooling process of $\mathrm{P}_{222(1 \mathrm{O})}(\mathrm{FH})_{2.1} \mathrm{~F}$, crystallization of $\mathrm{P}_{222(1 \mathrm{O} 1)}(\mathrm{FH})_{3} \mathrm{~F}$ and $\mathrm{P}_{222(1 \mathrm{O} 1)}(\mathrm{FH})_{2} \mathrm{~F}$ is observed. A small portion of the residual supercooled liquid crystallizes in the heating process and melting of $\mathrm{P}_{222(1 \mathrm{O})}(\mathrm{FH})_{3} \mathrm{~F}$ and $\mathrm{P}_{222(1 \mathrm{O})}(\mathrm{FH})_{2} \mathrm{~F}$ occur at $-67^{\circ} \mathrm{C}$ and $-34^{\circ} \mathrm{C}$, respectively.

Thermogravimetric curves for $\mathrm{P}_{222 m}(\mathrm{FH})_{2.1} \mathrm{Fs}$ are shown in Figure 3 with those for some previously reported fluorohydrogenate ILs, $\mathrm{P}_{4441}(\mathrm{FH})_{2.3} \mathrm{~F}, \operatorname{EMPyr}(\mathrm{FH})_{2.3} \mathrm{~F}$, and $\operatorname{EMIm}(\mathrm{FH})_{2.3} \mathrm{~F}\left(\mathrm{P}_{4441}=\right.$ tri- $n$ butylmethylphosphonium, EMPyr $=N$-ethyl- $N$-methylpyrrolidinium, and EMIm $=1$-ethyl-3methylimidazolium), for comparison. ${ }^{53}$ Fluorohydrogenate ILs gradually lose their weights on the heating process and show a large weight loss at a certain temperature. A gradual weight loss of the former is caused by slow HF release from the anion and a large weight loss of the latter is by irreversible decomposition involving cations. ${ }^{53}$ Improvement in thermal stability resulting from introduction of the phosphonium-based cations is reflected to the higher irreversible decomposition temperature for $\mathrm{P}_{2225}(\mathrm{FH})_{2.1} \mathrm{~F}$ and $\mathrm{P}_{2228}(\mathrm{FH})_{2.1} \mathrm{~F}$ compared to those of the $N$-heterocyclic ammonium salts, as well as that for $\mathrm{P}_{4441}(\mathrm{FH})_{2.3} \mathrm{~F}^{53}$. These irreversible decomposition temperatures of $\mathrm{P}_{2225}(\mathrm{FH})_{2.1} \mathrm{~F}$ and $\mathrm{P}_{2228}(\mathrm{FH})_{2.1} \mathrm{~F}$ are lower than those of phosphonium-based ILs for $\mathrm{P}_{2225} \mathrm{~N}\left(\mathrm{SO}_{2} \mathrm{CF}_{3}\right)_{2}{ }^{18}$ and $\mathrm{P}_{4448} \mathrm{BF}_{4}{ }^{19}$ $\left(\mathrm{N}\left(\mathrm{SO}_{2} \mathrm{CF}_{3}\right)_{2}=\right.$ bis(trifluoromethylsulfonyl)amide, $\mathrm{P}_{4448}=$ tri- $n$-butyl- $n$-octylphosphonium, and $\mathrm{BF}_{4}=$ 
tetrafluoroborate) by approximately $100^{\circ} \mathrm{C}$ due to the high nucleophilicity of $(\mathrm{FH})_{n} \mathrm{~F}^{-}$. The irreversible decomposition temperature of $\mathrm{P}_{222(1 \mathrm{O})}(\mathrm{FH})_{2.1} \mathrm{~F}$ is significantly lower than those of other phosphonium fluorohydrogenate ILs. ${ }^{53}$ 


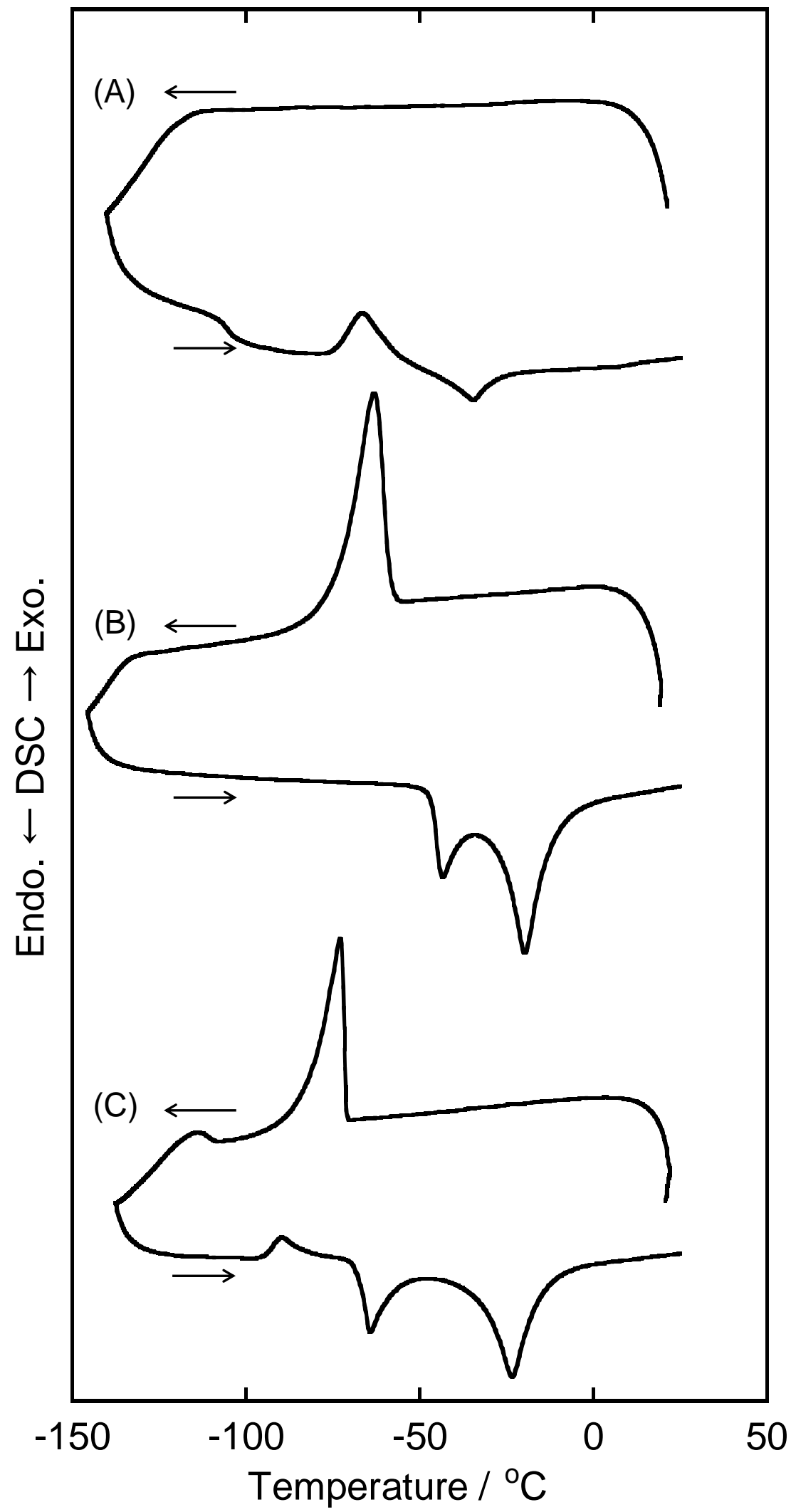

Figure 2. Differential scanning calorimetric curves of $\mathrm{P}_{222 m}(\mathrm{FH})_{2.1} \mathrm{Fs}(m=5$, 8, and 1O1); (A) $\mathrm{P}_{2225}(\mathrm{FH})_{2.1} \mathrm{~F},(\mathrm{~B}) \mathrm{P}_{2228}(\mathrm{FH})_{2.1} \mathrm{~F}$, and $(\mathrm{C}) \mathrm{P}_{222(1 \mathrm{O})}(\mathrm{FH})_{2.1} \mathrm{~F}$. Scan rate of $5^{\circ} \mathrm{C} \mathrm{min}^{-1}$ was used. 


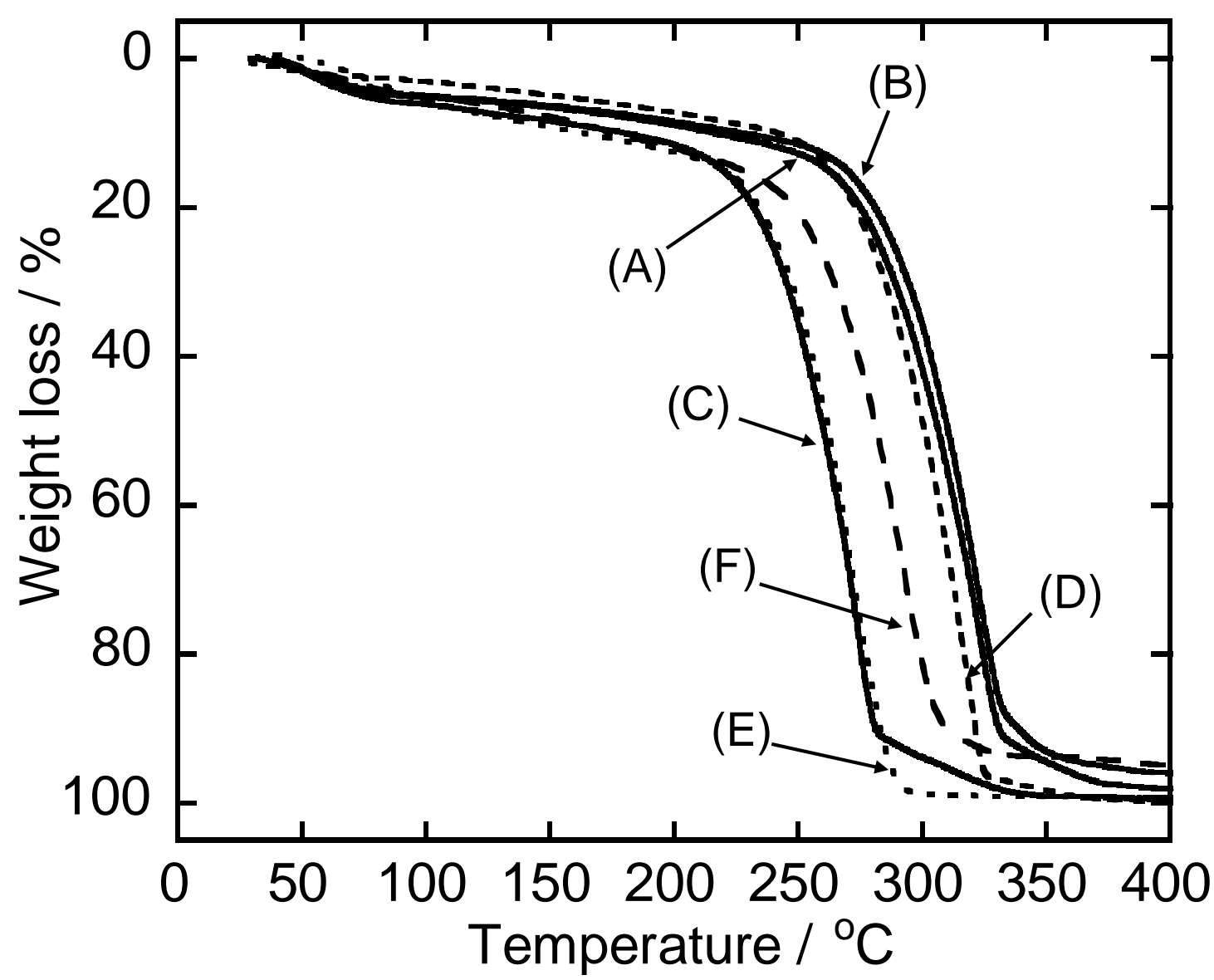

Figure 3. Thermogravimetric curves of $\mathrm{P}_{222 m}(\mathrm{FH})_{2.1} \mathrm{Fs}(m=5,8$, and $1 \mathrm{O} 1)$; $(\mathrm{A}) \mathrm{P}_{2225}(\mathrm{FH})_{2.1} \mathrm{~F},(\mathrm{~B})$ $\mathrm{P}_{2228}(\mathrm{FH})_{2.1} \mathrm{~F},(\mathrm{C}) \mathrm{P}_{222(101)}(\mathrm{FH})_{2.1} \mathrm{~F},(\mathrm{D}) \mathrm{P}_{4441}(\mathrm{FH})_{2.3} \mathrm{~F}$, (E) EMPyr(FH) ${ }_{2.3} \mathrm{~F}$, and (F) EMIm(FH) ${ }_{2.3} \mathrm{~F}$. Scan rate of $10^{\circ} \mathrm{C} \min ^{-1}$ was used. For the data of $\mathrm{P}_{4441}(\mathrm{FH})_{2.3} \mathrm{~F}, \mathrm{EMPyr}(\mathrm{FH})_{2.3} \mathrm{~F}$, and $\mathrm{EMIm}(\mathrm{FH})_{2.3} \mathrm{~F}$, see ref. 53.

Arrhenius plots of viscosity and conductivity for $\mathrm{P}_{222 m}(\mathrm{FH})_{2.1} \mathrm{Fs}$ are shown in Figure 4 . The plots show nearly linear dependence in the measured temperature range $\left(5-65^{\circ} \mathrm{C}\right)$. The $\mathrm{P}_{2225}(\mathrm{FH})_{2.1} \mathrm{~F}$ exhibits a lower viscosity and higher conductivity than $\mathrm{P}_{2228}(\mathrm{FH})_{2.1} \mathrm{~F}$ because of the smaller molecular size of $\mathrm{P}_{2225}{ }^{+}$. The similar trend was also seen in $N$-heterocyclic ammonium fluorohydrogenate ILs. ${ }^{19,47-52}$ Compared to $\mathrm{P}_{2225}(\mathrm{FH})_{2.1} \mathrm{~F}$ and $\mathrm{P}_{2228}(\mathrm{FH})_{2.1} \mathrm{~F}, \mathrm{P}_{222(1 \mathrm{O})}(\mathrm{FH})_{2.1} \mathrm{~F}$ exhibits a lower viscosity and a higher 


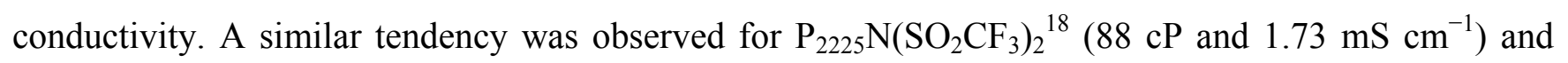
$\mathrm{P}_{222(101)} \mathrm{N}\left(\mathrm{SO}_{2} \mathrm{CF}_{3}\right)_{2}\left(35 \mathrm{cP}\right.$ and $\left.4.40 \mathrm{mS} \mathrm{cm}{ }^{-1}\right),{ }^{18}$ which was explained by a number of stable conformations with respect to the $\mathrm{C}-\mathrm{O}$ bond and the low energetic barrier for the corresponding rotation $^{63}$. Activation energies calculated from the Arrhenius plots are listed in Table 1. The activation energies of viscosity and conductivity decrease in the order of $\mathrm{P}_{2228}(\mathrm{FH})_{2.1} \mathrm{~F}>\mathrm{P}_{2225}(\mathrm{FH})_{2.1} \mathrm{~F}>$ $\mathrm{P}_{222(1 \mathrm{O})}(\mathrm{FH})_{2.1} \mathrm{~F}$. The low activation energies of viscosity and conductivity for $\mathrm{P}_{222 m}(\mathrm{FH})_{2.1} \mathrm{~F}$ are derived from HF exchange between the anions as previously proposed. ${ }^{54}$

Selected physical properties of $\mathrm{P}_{222 m}(\mathrm{FH})_{2.1} \mathrm{~F}$ are listed in Table 2 with $\mathrm{P}_{4441}(\mathrm{FH})_{2.3} \mathrm{~F}^{53}$, EMPyr $(\mathrm{FH})_{2.3} \mathrm{~F}^{50}, \mathrm{P}_{4441} \mathrm{~N}\left(\mathrm{SO}_{2} \mathrm{CF}_{3}\right)_{2}{ }^{64}, \mathrm{P}_{2225} \mathrm{~N}\left(\mathrm{SO}_{2} \mathrm{CF}_{3}\right)_{2}{ }^{18}, \mathrm{P}_{222(1 \mathrm{O})} \mathrm{N}_{(}\left(\mathrm{SO}_{2} \mathrm{CF}_{3}\right)_{2}{ }^{18}$, and $\mathrm{P}_{4448} \mathrm{BF}_{4}{ }^{64}$. The present phosphonium fluorohydrogenate ILs are far less viscous and more conductive than the phosphonium-based ILs combined with the other anions, and the viscosity and conductivity of $\mathrm{P}_{222(101)}(\mathrm{FH})_{2.1} \mathrm{~F}$ are the lowest and highest, respectively, in the phosphonium-based ILs reported so far. Viscosity and conductivity of the phosphonium-based fluorohydrogenate ILs are, roughly speaking, governed by the molecular weight of the cation; $\mathrm{P}_{2225}(\mathrm{FH})_{2.1} \mathrm{~F}$ and $\mathrm{P}_{222(101)}(\mathrm{FH})_{2.1} \mathrm{~F}$ exhibit a lower viscosity and higher conductivity than $\mathrm{P}_{4441}(\mathrm{FH})_{2.3} \mathrm{~F}$, and $\mathrm{P}_{2228}(\mathrm{FH})_{2.1} \mathrm{~F}$ exhibits almost the same viscosity and conductivity as those of $\mathrm{P}_{4441}(\mathrm{FH})_{2.3} \mathrm{~F}$. Correlation between molecular volume and viscosity for some ILs was shown in a previous work ${ }^{65}$, whereas comparison of viscosities for the three $\mathrm{P}_{222 m}(\mathrm{FH})_{2.1} \mathrm{~F}$ ILs clearly shows that introduction of methoxymethyl group has a big influence on viscosity and correlation between molecular volume and viscosity does not hold in such a case. 

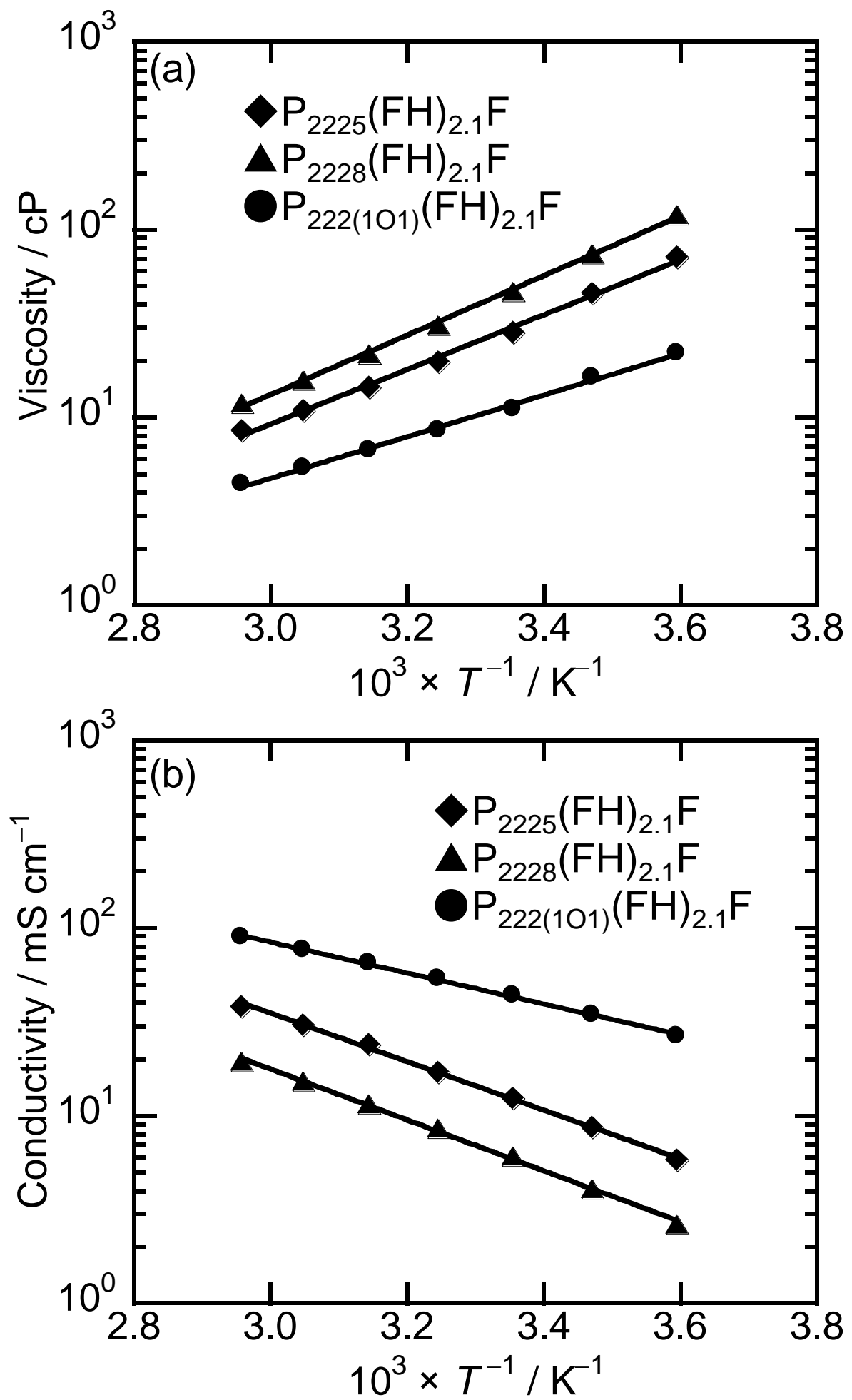

Figure 4. Arrhenius plots of (a) viscosity and (b) conductivity for $\mathrm{P}_{222 m}(\mathrm{FH})_{2.1} \mathrm{Fs}(m=5$, 8, and 1O1). 
Table 1. Activation energies of viscosity and conductivity for $\mathrm{P}_{222 m}(\mathrm{FH})_{2.1} \mathrm{Fs}(m=5,8 \text {, and } 1 \mathrm{O} 1)^{a}$

\begin{tabular}{llll}
\hline Activation energy & $\mathrm{P}_{222(1 \mathrm{O})}(\mathrm{FH})_{2.1} \mathrm{~F}$ & $\mathrm{P}_{2225}(\mathrm{FH})_{2.1} \mathrm{~F}$ & $\mathrm{P}_{2228}(\mathrm{FH})_{2.1} \mathrm{~F}$ \\
\hline$E_{\mathrm{a}}(\eta) / \mathrm{kJ} \mathrm{mol}^{-1}$ & 21.0 & 27.8 & 30.2 \\
$E_{\mathrm{a}}(\sigma) / \mathrm{kJ} \mathrm{mol}^{-1}$ & 15.7 & 24.7 & 25.9 \\
\hline${ }^{a} E_{\mathrm{a}}(\eta)$ and $E_{\mathrm{a}}(\sigma):$ activation energies of viscosity and conductivity, respectively. \\
\hline
\end{tabular}

Table 2. Physical properties of selected ILs ${ }^{a}$

\begin{tabular}{llllll}
\hline $\mathrm{IL}$ & $\mathrm{FW}$ & $T_{\mathrm{m}}\left(T_{\mathrm{g}}\right) /{ }^{\circ} \mathrm{C}$ & $\rho / \mathrm{g} \mathrm{cm}^{-3}$ & $\eta / \mathrm{cP}$ & $\sigma / \mathrm{mS} \mathrm{cm}^{-1}$ \\
\hline $\mathrm{P}_{222(1 \mathrm{O} 1)}(\mathrm{FH})_{2.1} \mathrm{~F}$ & 224 & $-67,-34$ & 1.07 & 11 & 43.9 \\
$\mathrm{P}_{2225}(\mathrm{FH})_{2.1} \mathrm{~F}$ & 250 & $(-107),-55$ & 0.999 & 28 & 12.4 \\
$\mathrm{P}_{2228}(\mathrm{FH})_{2.1} \mathrm{~F}$ & 292 & $-46,-27$ & 0.968 & 47 & 6.1 \\
\hline $\mathrm{P}_{4441}(\mathrm{FH})_{2.3} \mathrm{~F}^{b}$ & 282 & $(-104),-24$ & 0.969 & 36 & 6.0 \\
$\mathrm{EMPyr}(\mathrm{FH})_{2.3} \mathrm{~F}^{c}$ & 179 & $<-128$ & 1.07 & 11.5 & 74.6 \\
$\mathrm{P}_{4441} \mathrm{~N}\left(\mathrm{SO}_{2} \mathrm{CF}_{3}\right)_{2}{ }^{d}$ & 498 & 16 & 1.28 & 207 & 0.416 \\
$\mathrm{P}_{2225} \mathrm{~N}\left(\mathrm{SO}_{2} \mathrm{CF}_{3}\right)_{2}{ }^{e}$ & 469 & 17 & 1.32 & 88 & 1.73 \\
$\mathrm{P}_{222(101)} \mathrm{N}_{\left(\mathrm{SO}_{2} \mathrm{CF}_{3}\right)_{2}{ }^{e}}$ & 443 & 14 & 1.42 & 35 & 4.40 \\
$\mathrm{P}_{4448} \mathrm{BF}_{4}{ }^{d}$ & 402 & $<-50$ & 1.02 & 1240 & 0.069 \\
\hline
\end{tabular}

\begin{abstract}
${ }^{a} \mathrm{FW}$ : formula weight, $T_{\mathrm{m}}$ : melting point, $T_{\mathrm{g}}$ : glass transition temperature, $\rho$ : density at $25^{\circ} \mathrm{C}, \quad \eta$ : viscosity at $25^{\circ} \mathrm{C}, \sigma$ : conductivity at $25^{\circ} \mathrm{C} . \mathrm{P}_{222(1 \mathrm{O} 1)}$ : triethylmethoxymethylphosphonium, $\mathrm{P}_{2225}$ : triethyl-n-pentylphosphonium, $\mathrm{P}_{2228}$ : triethyl- $n$-octylphosphonium, $\mathrm{P}_{4441}$ : tri- $n$-butylmethylphosphonium, $\mathrm{P}_{4448}$ : tri- $n$-butyl- $n$ octylphosphonium, EMPyr: $\quad N$-ethyl- $N$-methylpyrrolidinium, $\quad \mathrm{N}\left(\mathrm{SO}_{2} \mathrm{CF}_{3}\right)_{2}$ : bis(trifluoromethylsulfonyl)amide, and $\mathrm{BF}_{4}$ : tetrafluoroborate. ${ }^{b}$ Ref. 53. ${ }^{c}$ Ref. 50. ${ }^{d}$ ref. 64. ${ }^{e}$ Ref. 18.
\end{abstract}

Linear sweep voltammograms of glassy carbon and platinum electrodes in $\mathrm{P}_{222 m}(\mathrm{FH})_{2.1} \mathrm{Fs}$ are shown in Figure 5 with the electrochemical windows of $\mathrm{P}_{4441}(\mathrm{FH})_{2.3} \mathrm{~F}^{53}, \mathrm{EMPyr}(\mathrm{FH})_{2.3} \mathrm{~F}^{50}$, and $\mathrm{EMIm}(\mathrm{FH})_{2.3} \mathrm{~F}^{19}$. Electrochemical windows of $\mathrm{P}_{222 m}(\mathrm{FH})_{2.1} \mathrm{Fs}$ with glassy carbon and platinum electrodes are listed in 
Table 3. The anode and cathode limits are determined as the potentials where the absolute values of the current densities exceed $0.5 \mathrm{~mA} \mathrm{~cm}^{-2}$ at the scan rate of $10 \mathrm{mV} \mathrm{s}^{-1}$. For a glassy carbon electrode, the $\mathrm{P}_{222 m}(\mathrm{FH})_{2.1} \mathrm{~F}$ ILs exhibit wide electrochemical windows exceeding $4.9 \mathrm{~V}$. In particular, the electrochemical window of $5.8 \mathrm{~V}$ for $\mathrm{P}_{2225}(\mathrm{FH})_{2.1} \mathrm{~F}$ and $\mathrm{P}_{2228}(\mathrm{FH})_{2.1} \mathrm{~F}$ is as wide as that for $\mathrm{P}_{4441}(\mathrm{FH})_{2.3} \mathrm{~F}$ $(6.0 \mathrm{~V})^{53}$, reflecting a high electrochemical stability of the phosphonium-based fluorohydrogenate ILs. The electrochemical window of $\mathrm{P}_{222(1 \mathrm{O})}(\mathrm{FH})_{2.1} \mathrm{~F}$ is narrower than those of other phosphonium fluorohydrogenate ILs because of the low electrochemical stability of the methoxymethyl group both at the cathode and anode limits. ${ }^{18}$ The cathode limits of the phosphonium fluorohydrogenate ILs on a glassy carbon electrode are more negative than those of fluorohydrogenate ILs with the other cations, although the cathode limits on a platinum electrode are around $-1 \mathrm{~V}$ vs. the $\mathrm{Fc}^{+} / \mathrm{Fc}$ redox couple regardless of the cations. ${ }^{53}$ The cathode limit reaction of fluorohydrogenate salts is hydrogen gas evolution from $(\mathrm{FH})_{n} \mathrm{~F}^{-}$if the cation has a sufficient stability against reduction. ${ }^{52,66-68}$ The present results suggest that the overpotential of hydrogen gas evolution from $(\mathrm{FH})_{n} \mathrm{~F}^{-}$depends on the electrode material as well as the cationic structure. Another reduction wave is observed from $-3.0 \mathrm{~V} v s . \mathrm{Fc}^{+} / \mathrm{Fc}$ with a platinum electrode for $\mathrm{P}_{2228}(\mathrm{FH})_{2.1} \mathrm{~F}$ and is assigned to the decomposition of the cation which is probably the same reaction as the cathode limit on a glassy carbon electrode. The anode limits of $\mathrm{P}_{222 m}(\mathrm{FH})_{2.1} \mathrm{Fs}$ vary from 2.3 to $2.9 \mathrm{~V} v s . \mathrm{Fc}^{+} / \mathrm{Fc}$, which corresponds to decomposition of the cations. ${ }^{53}$ The anode limits shift to the lower potential with extension of the side-chain $\left(2.94 \mathrm{~V}\right.$ for $\mathrm{P}_{2225}(\mathrm{FH})_{2.1} \mathrm{~F}$ and $2.74 \mathrm{~V}$ for $\left.\mathrm{P}_{2228}(\mathrm{FH})_{2.1} \mathrm{~F}\right)$. A similar trend was observed in the cases of $\mathrm{P}_{444 m}(\mathrm{FH})_{2.3} \mathrm{~F}(m=1,4$, and $8) .^{53}$ 

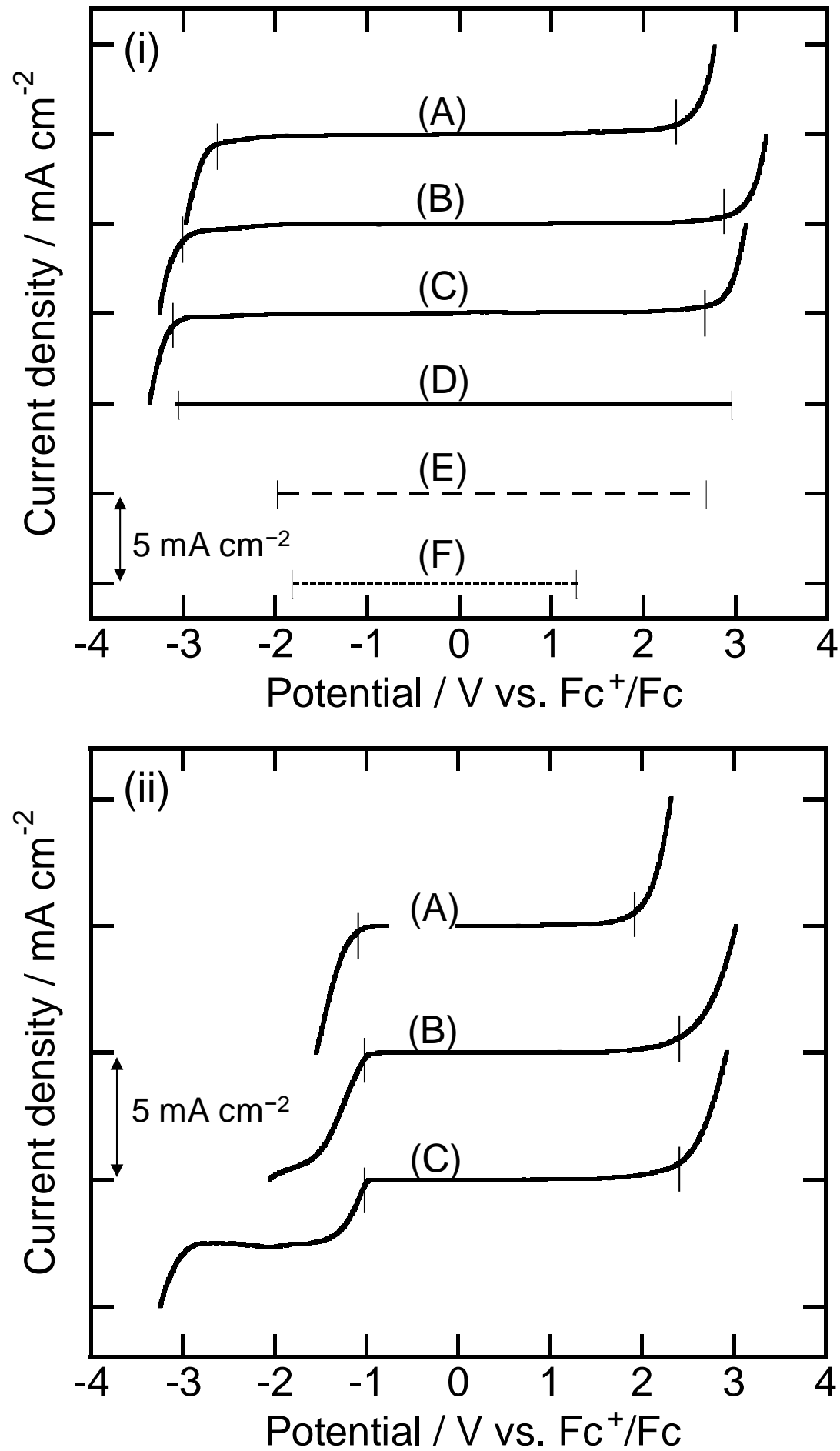

Figure 5. Linear sweep voltammograms of (i) glassy carbon and (ii) platinum electrodes in $\mathrm{P}_{222 m}(\mathrm{FH})_{2.1} \mathrm{Fs}\left(m=5,8\right.$, and 1O1); (A) $\mathrm{P}_{222(1 \mathrm{O})}(\mathrm{FH})_{2.1} \mathrm{~F},(\mathrm{~B}) \mathrm{P}_{2225}(\mathrm{FH})_{2.1} \mathrm{~F},(\mathrm{C}) \mathrm{P}_{2228}(\mathrm{FH})_{2.1} \mathrm{~F},(\mathrm{D})$ $\mathrm{P}_{4441}(\mathrm{FH})_{2.3} \mathrm{~F},(\mathrm{E}) \mathrm{EMPyr}(\mathrm{FH})_{2.3} \mathrm{~F}$, and $(\mathrm{F}) \mathrm{EMIm}(\mathrm{FH})_{2.3} \mathrm{~F}$. Vertical lines denote the anode and cathode limits determined as the potentials where the absolute values of the current densities exceed $0.5 \mathrm{~mA}$ 
$\mathrm{cm}^{-2}$ at the scan rate of $10 \mathrm{mV} \mathrm{s}^{-1}$. For the data of $\mathrm{P}_{4441}(\mathrm{FH})_{2.3} \mathrm{~F}, \operatorname{EMPyr}(\mathrm{FH})_{2.3} \mathrm{~F}$, and $\mathrm{EMIm}(\mathrm{FH})_{2.3} \mathrm{~F}$, see refs. 53, 50, and 19 , respectively.

Table 3. Electrochemical windows of $\mathrm{P}_{222 m}(\mathrm{FH})_{2.1} \mathrm{Fs}\left(m=5,8\right.$, and 1O1) ${ }^{a}$

\begin{tabular}{|c|c|c|c|c|}
\hline \multirow{2}{*}{ IL } & \multicolumn{2}{|c|}{ Glassy carbon electrode } & \multicolumn{2}{|c|}{ Platinum electrode } \\
\hline & $E_{\mathrm{an}} / \mathrm{V}$ & $E_{\mathrm{ca}} / \mathrm{V}$ & $E_{\text {an }} / \mathrm{V}$ & $E_{\mathrm{ca}} / \mathrm{V}$ \\
\hline $\mathrm{P}_{222(1 \mathrm{O} 1)}(\mathrm{FH})_{2.1} \mathrm{~F}$ & -2.58 & 2.34 & -1.17 & 1.90 \\
\hline $\mathrm{P}_{2225}(\mathrm{FH})_{2.1} \mathrm{~F}$ & -2.87 & 2.94 & -1.06 & 2.35 \\
\hline $\mathrm{P}_{2228}(\mathrm{FH})_{2.1} \mathrm{~F}$ & -3.07 & 2.74 & -1.05 & 2.33 \\
\hline
\end{tabular}

Properties and plastic crystal structures of $\mathbf{P}_{\mathbf{2 2 2 2}}(\mathbf{F H})_{2} \mathbf{F}$. The reaction of $\mathrm{P}_{2222} \mathrm{Br}$ and $\mathrm{HF}$ gave a white solid with the HF composition formulated as $\mathrm{P}_{2222}(\mathrm{FH})_{2.2} \mathrm{~F}$. The $\mathrm{P}_{2222}(\mathrm{FH})_{2.2} \mathrm{~F}$ is vacuum-stable and shows plastic crystalline behavior around room temperature (see Figure S2, ESI $\uparrow$ for the DSC curve). In order to obtain simple data, further investigation was performed on $\mathrm{P}_{2222}(\mathrm{FH})_{2} \mathrm{~F}$ containing a single anion, $(\mathrm{FH})_{2} \mathrm{~F}^{-}$. The $\mathrm{P}_{2222}(\mathrm{FH})_{2} \mathrm{~F}$ salt was obtained by mixing $\mathrm{P}_{2222}(\mathrm{FH})_{2.2} \mathrm{~F}$ and $\mathrm{P}_{2222}(\mathrm{FH})_{1.9} \mathrm{~F}$ in a stoichiometric ratio, since the HF unit in fluorohydrogenate anions are exchanged and quickly reach equilibrium when two fluorohydrogenate ILs with different HF compositions are mixed. ${ }^{27,49}$ A DSC curve of $\mathrm{P}_{2222}(\mathrm{FH})_{2} \mathrm{~F}$ is shown in Figure 6. In the heating process, three phase transitions are observed with the entropy changes $(\Delta S)$ of $8 \mathrm{~J} \mathrm{~K}^{-1} \mathrm{~mol}^{-1}$ (enthalpy change, $\Delta H=-2690 \mathrm{~J} \mathrm{~mol}^{-1}$ at $60^{\circ} \mathrm{C}$ ), $19 \mathrm{~J} \mathrm{~K}^{-1}$ $\mathrm{mol}^{-1}\left(\Delta H=-5680 \mathrm{~J} \mathrm{~mol}^{-1}\right.$ at $\left.32^{\circ} \mathrm{C}\right)$, and $33 \mathrm{~J} \mathrm{~K}^{-1} \mathrm{~mol}^{-1}\left(\Delta H=-9130 \mathrm{~J} \mathrm{~mol}^{-1}\right.$ at $\left.6^{\circ} \mathrm{C}\right)$, respectively. 
Timmermans pointed out that the plastic crystal phase of a molecular compound has a low entropy change of fusion $\left(\Delta S_{\text {fus }}<20 \mathrm{~J} \mathrm{~K}^{-1} \mathrm{~mol}^{-1}\right){ }^{69}$ The transition at $60^{\circ} \mathrm{C}$ for $\mathrm{P}_{2222}(\mathrm{FH})_{2} \mathrm{~F}$ satisfies this criterion $\left(\Delta S_{\text {fus }}=8 \mathrm{~J} \mathrm{~K}^{-1} \mathrm{~mol}^{-1}\right)$, suggesting the phase between 32 and $60^{\circ} \mathrm{C}$ is plastic crystal. The phase between 6 and $32^{\circ} \mathrm{C}$ is also considered to be plastic crystal phase due to its simple XRD pattern and high conductivity (discussed later) as well as its appearance and softness $\left(\Delta S=19 \mathrm{~J} \mathrm{~K}^{-1} \mathrm{~mol}^{-1}\right.$ at $\left.32^{\circ} \mathrm{C}\right)$. Consequently, $\mathrm{P}_{2222}(\mathrm{FH})_{2} \mathrm{~F}$ has one crystal, two plastic crystal (PC II and I), and one liquid phases in this temperature range.

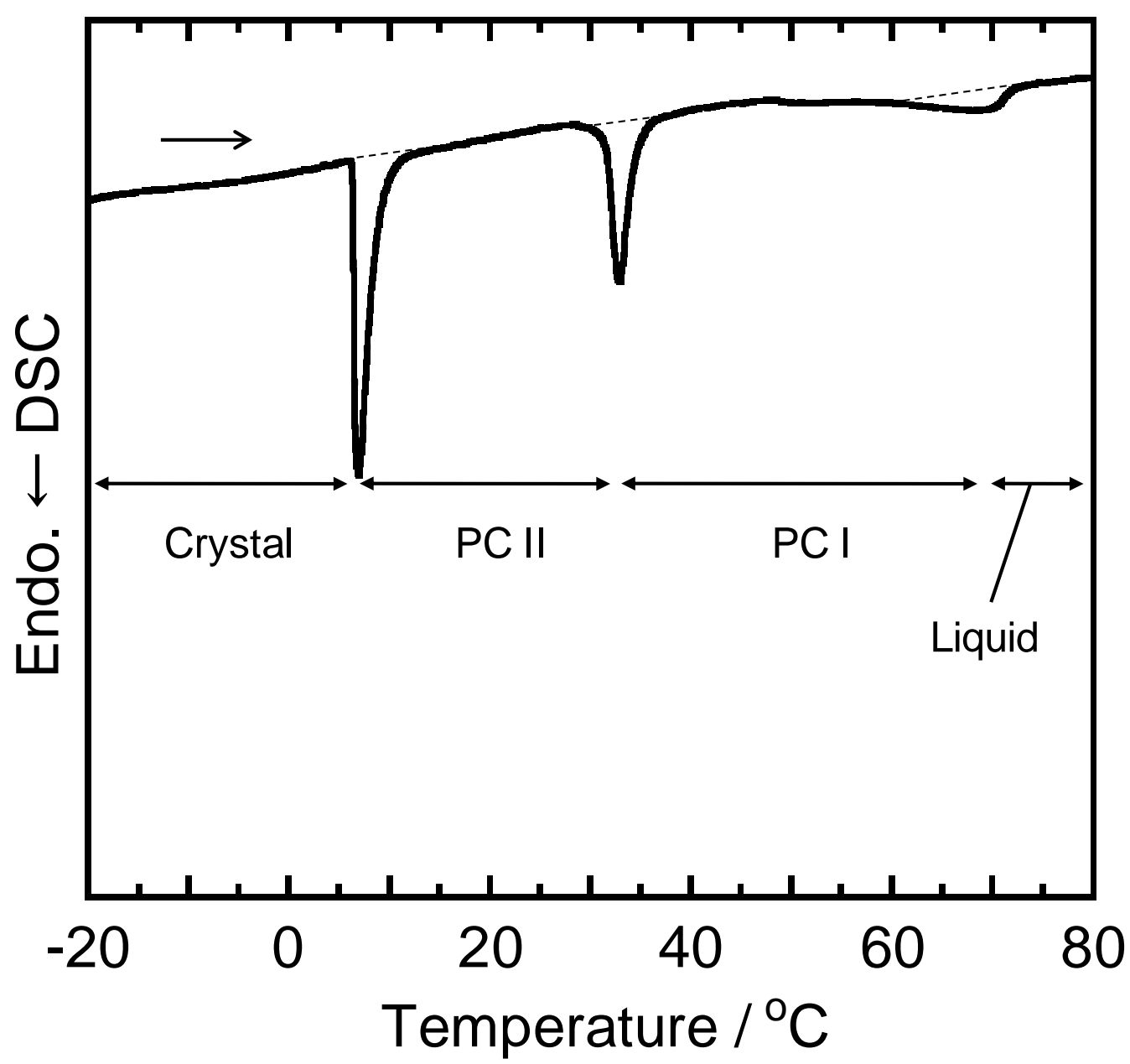

Figure 6. The DSC curve of $\mathrm{P}_{2222}(\mathrm{FH})_{2} \mathrm{~F}$. Scan rate of $1^{\circ} \mathrm{C} \mathrm{min}-1$ was used. 
An Arrhenius plot of conductivity for $\mathrm{P}_{2222}(\mathrm{FH})_{2} \mathrm{~F}$ is shown in Figure 7 . The conductivity was measured at a temperature range between 15 and $95^{\circ} \mathrm{C}$ in the heating process. The conductivity of liquid phase is $106 \mathrm{mS} \mathrm{cm}^{-1}$ at $80{ }^{\circ} \mathrm{C}$ and those of the plastic crystal phases are $5 \mathrm{mS} \mathrm{cm}^{-1}$ at $50^{\circ} \mathrm{C}(\mathrm{PC} \mathrm{I})$ and $0.03 \mathrm{mS} \mathrm{cm}^{-1}$ at $25^{\circ} \mathrm{C}(\mathrm{PC} \mathrm{II})$. This conductivity of the PC I phase is the highest value in the neat ionic plastic crystals reported so far.

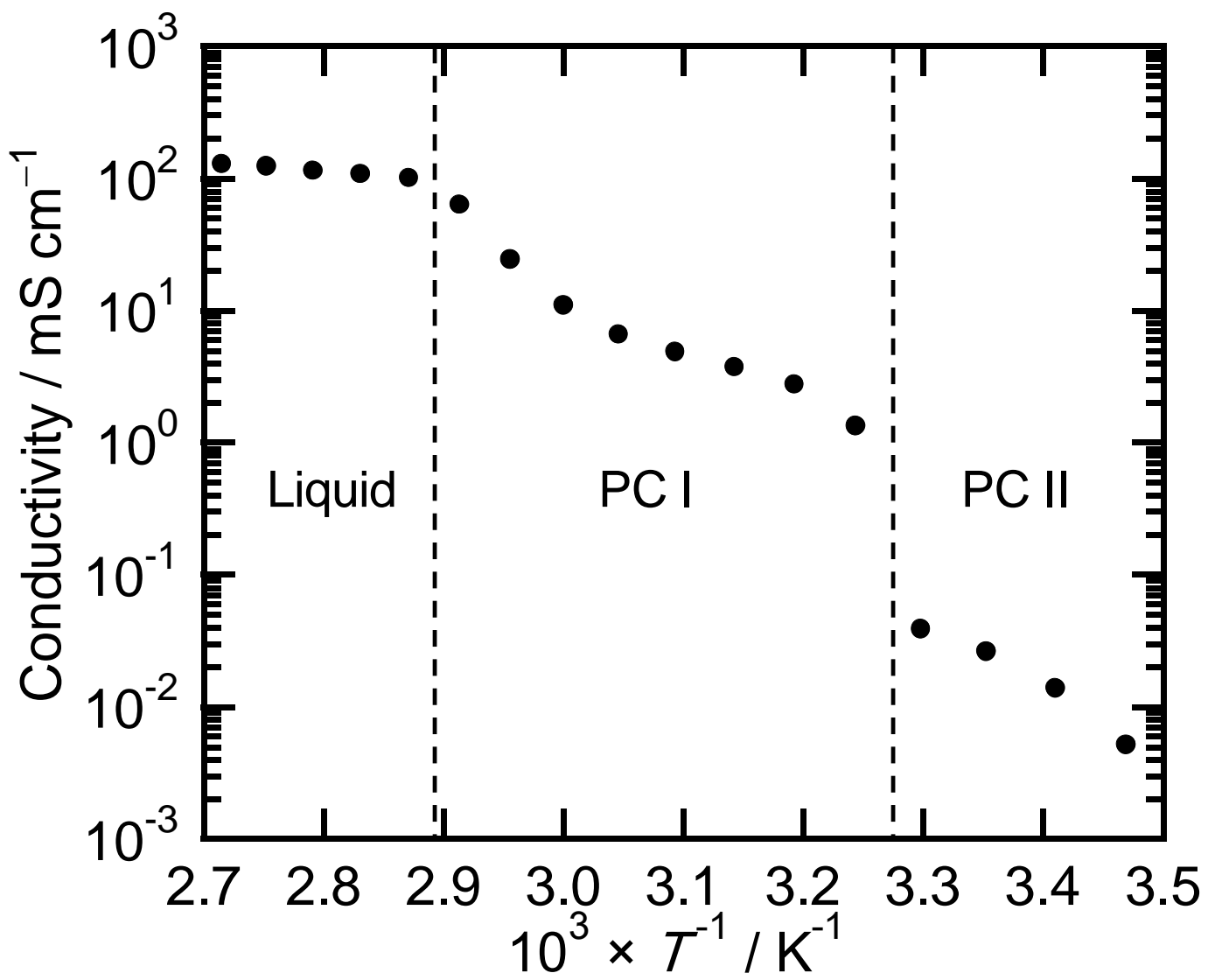

Figure 7. Arrhenius plot of conductivity for $\mathrm{P}_{2222}(\mathrm{FH})_{2} \mathrm{~F}$.

The data of crystal structures determined by single-crystal XRD measurement at low temperatures, which are occasionally combined with spectroscopic data, provide important insights in the phase transition mechanism and the ion disordering mode in plastic crystal phases. ${ }^{70-73}$ Unfortunately, the poor 
quality of crystals did not allow single-crystal diffraction analysis in the present case. Instead, the structure of the plastic crystal phases will be discussed here based on powder X-ray diffraction. X-ray diffraction patterns of $\mathrm{P}_{2222}(\mathrm{FH})_{2} \mathrm{~F}$ at $35^{\circ} \mathrm{C}$ (PC I phase), $10^{\circ} \mathrm{C}$ (PC II phase), and $-10^{\circ} \mathrm{C}$ (Crystal phase) are shown in Figure 8. In some plastic crystal phases, the cations and anions rotate and form a spherical shape, resulting in a plastic crystal lattice with high symmetry such as cubic lattice. ${ }^{74,75}$ The XRD patterns at $35^{\circ} \mathrm{C}$ (PC I) and $10^{\circ} \mathrm{C}$ (PC II) are relatively simple without strong diffraction peaks at high $2 \theta$-angles, reflecting the large thermal motions of the constituent ions. The XRD pattern of PC I $\left(35^{\circ} \mathrm{C}\right)$ is indexed as a hexagonal lattice with the lattice constants of $a=8.02 \AA$ and $c=11.84 \AA$. Table 4 lists the $d$ values and indices with the calculated $d$ values which agree with the experimental $d$ values well. From the volume of unit cell $\left(V=660 \AA^{3}\right), Z$ for $\mathrm{P}_{2222}(\mathrm{FH})_{2} \mathrm{~F}$ is determined as two and the calculated density is $1.038 \mathrm{~g} \mathrm{~cm}^{-3}$. The spherical cations are considered to form a hexagonal close-packed structure and the anions exists in the interstices among them because the size of $\mathrm{P}_{2222}{ }^{+}$is larger than that of $(\mathrm{FH})_{2} \mathrm{~F}^{-}$. There are two types of interstitial sites for anions in the hexagonal close-packed structure of cations; one is the six-coordinated octahedral site and the other is the four-coordinate tetrahedral site (Figure 9). The octahedral site has a larger space than the tetrahedral site (in the present case the cationanion distances for the octahedral and tetrahedral sites are 5.5 and $4.8 \AA$, respectively). Occupation of the octahedral and tetrahedral sites correspond to the inverse nickel arsenide $\left(P 6_{3} / m m c\right)$ and wurtzite $\left(P 6_{3} m c\right)$ structure, respectively. ${ }^{76}$ In order to roughly estimate the size of the cation, the molecular structures were optimized by quantum mechanical calculation at the MP2/cc-pVTZ level (see Table S5, $\mathrm{ESI} \uparrow$ for the results at the other levels). From the optimized geometries (Figure 10), the longest distance 
between two atoms in $\mathrm{P}_{2222}{ }^{+}$is $7.23 \AA$ and that in $(\mathrm{FH})_{2} \mathrm{~F}^{-54}$ is $4.08 \AA$ at the MP2/cc-pVTZ level (See ref.

54 for the optimized structure of $(\mathrm{FH})_{2} \mathrm{~F}^{-}$). Assuming that the cations and anions rotate and form spherical shapes, the longest distances of the atoms are the diameters of the spheres and the radii are 3.6 $\AA$ for $\mathrm{P}_{2222}{ }^{+}$and $2.1 \AA$ for $(\mathrm{FH})_{2} \mathrm{~F}^{-}$(see Figure 10). The resulting sum of the cation and anion radii is 5.7 $\AA$, indicating that the tetrahedral site is too small for $(\mathrm{FH})_{2} \mathrm{~F}^{-}$. As a consequence, the plastic crystal structure (PC I) at $35^{\circ} \mathrm{C}$ has an inverse nickel arsenide structure in which the cations form the hexagonal close-packed structure and the anions occupy the octahedral sites of the cations (Figure 11). Structures of several ionic plastic crystals were investigated in previous works, and $\mathrm{NaCl}$ - and CsCl-type cubic phases are known as a high-temperature phase. ${ }^{75}$ Although there is an example of a salt with an inverse nickel arsenide-type crystal structure $\left(\mathrm{N}\left(\mathrm{CH}_{3}\right)_{4} \mathrm{~F}\right)^{77}$, the present case is the first example for ionic plastic crystals. Coordination number of an ion in a $\left[\mathrm{C}^{+}\right]\left[\mathrm{A}^{-}\right]$-type salt $\left(\mathrm{C}^{+}\right.$: singly charged cation, $\mathrm{A}^{-}$: singly charged anion) is roughly estimated from the radius-ratio rule. ${ }^{76}$ According to this rule, coordination number of an ion is 4 for $0.225<R_{-} / R_{+}<0.414,6$ for $0.414<R_{-} / R_{+}<0.732$, and 8 for $0.732<R_{-} / R_{+}<1$, where $R_{-}$and $R_{+}$are the radii of the anion and cation, respectively. The present case gives the radius ratio of 0.58 and the coordination number of 6 , which satisfies this rule.

The XRD pattern of PC II $\left(10^{\circ} \mathrm{C}\right)$ is indexed as an orthorhombic lattice $(P m m a)$ and the lattice constants of $a=11.43 \AA, b=8.13 \AA$, and $c=13.58 \AA$ are obtained (see Table 4 for the experimental and calculated $d$ values and indices). From the volume of unit cell $\left(V=1262 \AA^{3}\right), Z$ for $\mathrm{P}_{2222}(\mathrm{FH})_{2} \mathrm{~F}$ in PC(II) at $\left(10{ }^{\circ} \mathrm{C}\right)$ is determined as 4 and the calculated density is $1.086 \mathrm{~g} \mathrm{~cm}^{-3}$ which is slightly larger than that of PC I $\left(35^{\circ} \mathrm{C}\right)$. This orthorhombic lattice can be regarded as a distorted hexagonal lattice of 
PC I and the lattice parameters of $a, b$, and $c$ in PC II corresponds to $11.84,8.02$, and $13.89 \AA$ in PC I when the hexagonal lattice of PC I is reduced to the orthorhombic lattice (see Figure 11). The lattice is shrunk along the $a$ and $c$ axes and is expanded along the $b$ axis of PC II in the change from PC I to PC II. These changes which could be derived from the change in the rotational motion of the spherical ions result in the lowering of structural symmetry of the crystal lattice. The XRD pattern of the crystal phase $\left(-10^{\circ} \mathrm{C}\right)$ was not successful in indexing.

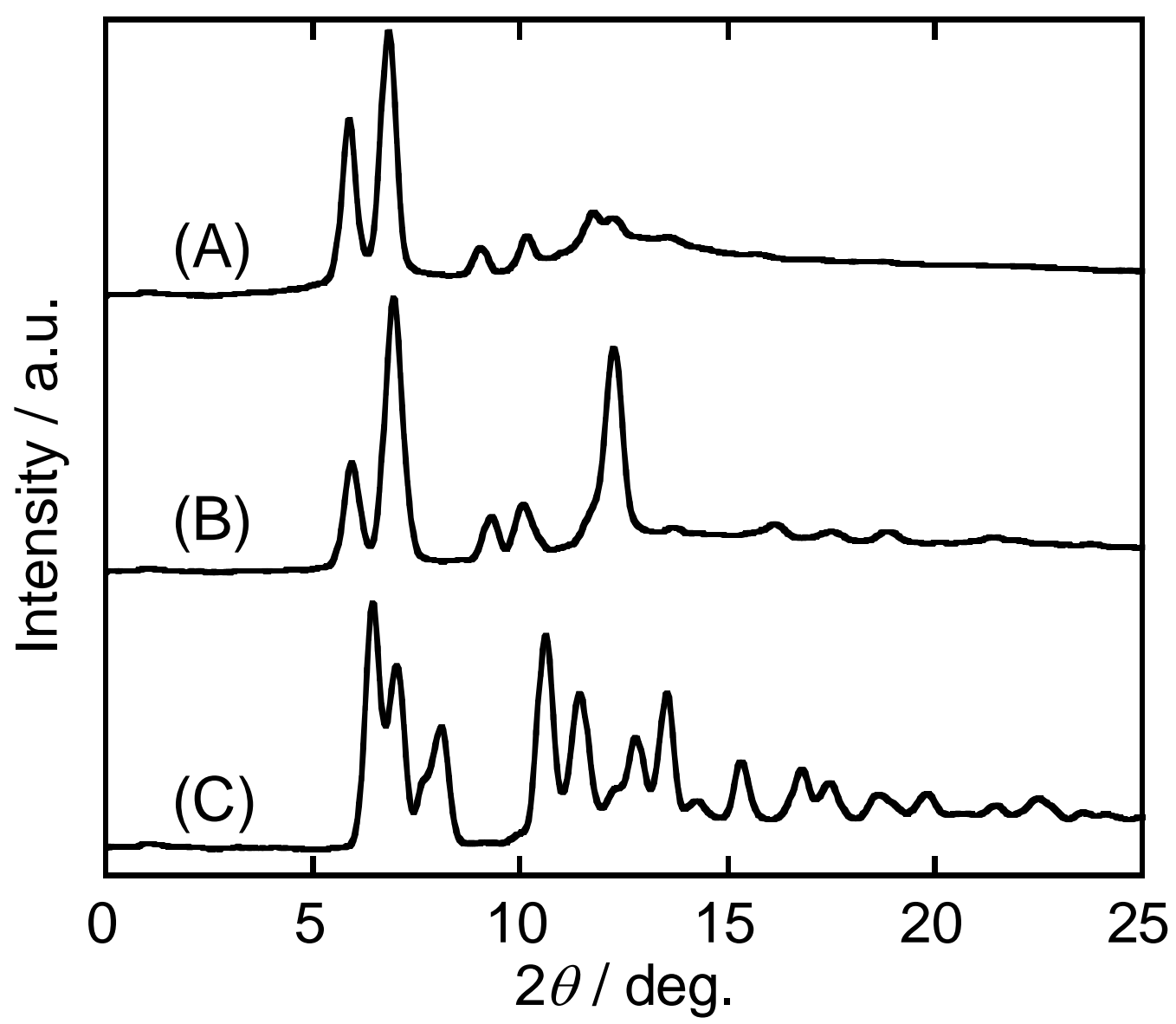

Figure 8. X-ray diffraction patterns of the (A) PC I $\left(35^{\circ} \mathrm{C}\right)$, (B) PC II $\left(10^{\circ} \mathrm{C}\right)$, and $(\mathrm{C})$ crystal $\left(-10^{\circ} \mathrm{C}\right)$ phases for $\mathrm{P}_{2222}(\mathrm{FH})_{2} \mathrm{~F}$. 
Table 4. Experimental and calculated $d$ values and indices for the PC I $\left(35^{\circ} \mathrm{C}\right.$, hexagonal) and PC II $\left(10^{\circ} \mathrm{C}\right.$, orthorhombic) phases of $\mathrm{P}_{2222}(\mathrm{FH})_{2} \mathrm{~F}$

\begin{tabular}{ccccc}
\hline$h$ & $k$ & $l$ & $d$ obs. $/ \AA$ & $d$ calc. $^{a} / \AA$ \\
\hline \multicolumn{5}{c}{ PC I $\left(35^{\circ} \mathrm{C}\right.$, hexagonal $)$} \\
1 & 0 & 0 & 6.93 & 6.95 \\
1 & 0 & 1 & 5.97 & 5.99 \\
1 & 0 & 2 & 4.50 & 4.51 \\
2 & 1 & 0 & 4.01 & 4.01 \\
2 & 0 & 0 & 3.47 & 3.47 \\
2 & 0 & 2 & 3.01 & 3.33 \\
2 & 0 & 3 & 2.61 & 3.00
\end{tabular}

PC II $\left(10^{\circ} \mathrm{C}\right.$, orthorhombic)

$\begin{array}{ccccc}0 & 0 & 2 & 6.86 & 6.79 \\ 1 & 0 & 2 & 5.87 & 5.84 \\ 2 & 0 & 2 & 4.38 & 4.37 \\ 0 & 2 & 0 & 4.05 & 4.06 \\ 2 & 2 & 0 & 3.33 & 3.31 \\ 2 & 2 & 2 & 2.98 & 2.98 \\ 3 & 0 & 4 & 2.53 & 2.53 \\ 4 & 2 & 0 & 2.33 & 2.34 \\ 5 & 0 & 2 & 2.17 & 2.17 \\ 2 & 4 & 0 & 1.91 \\ & & \end{array}$


(a) Inverse NiAs

(b) Wurtzite

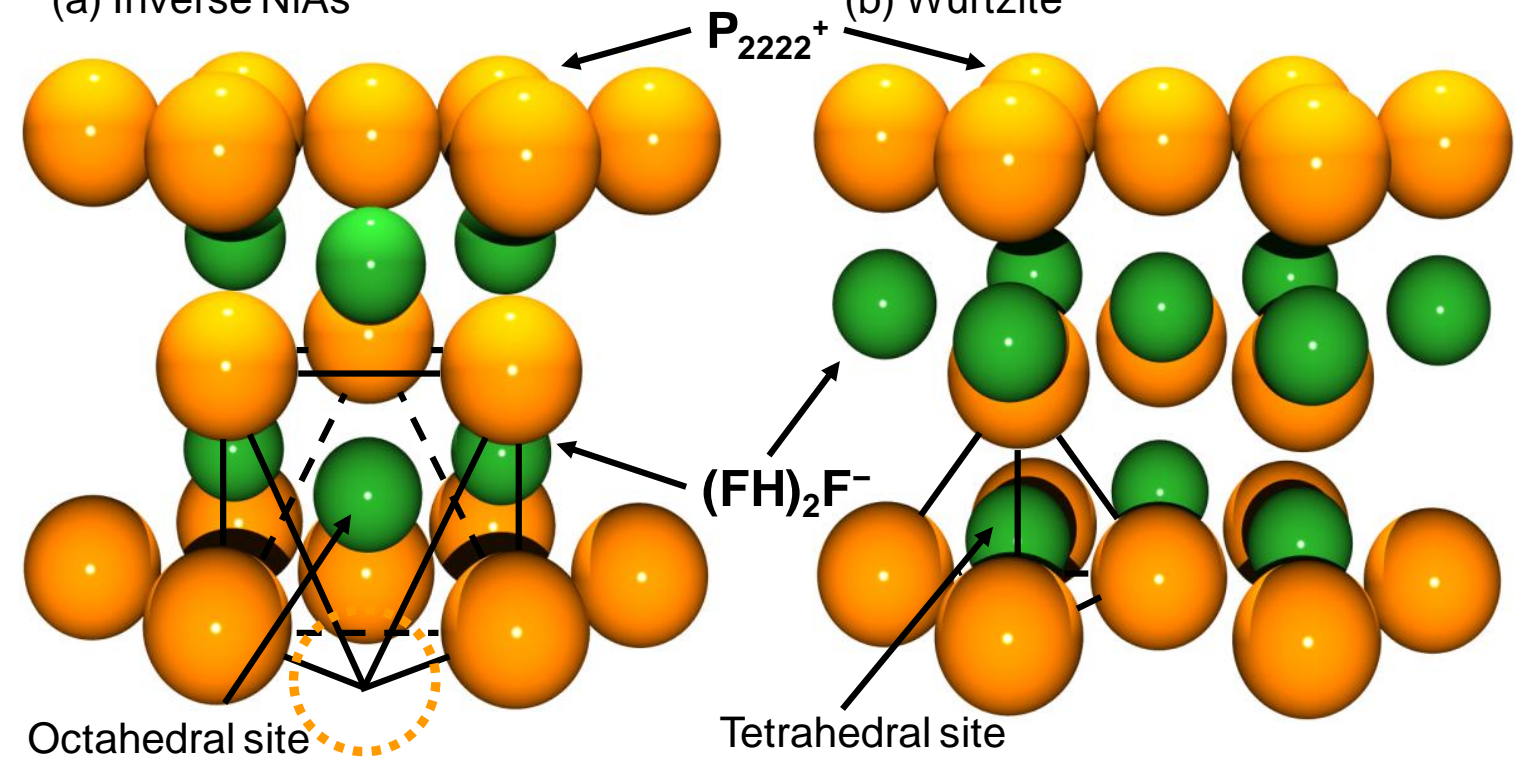

Figure 9. Schematic drawings of (a) inverse nickel arsenide and (b) wurtzite structures.

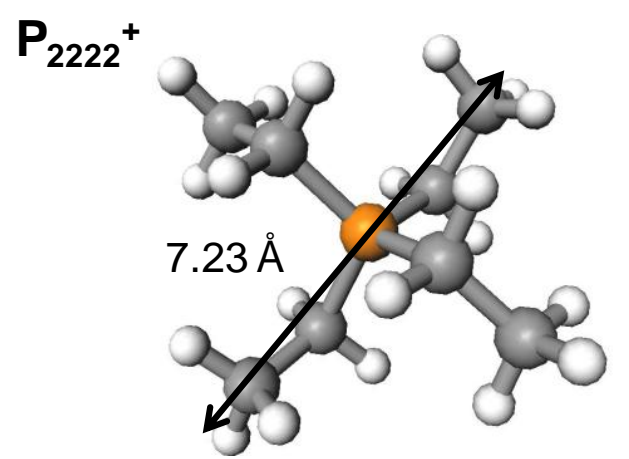

$(\mathrm{FH})_{2} \mathrm{~F}^{-}$
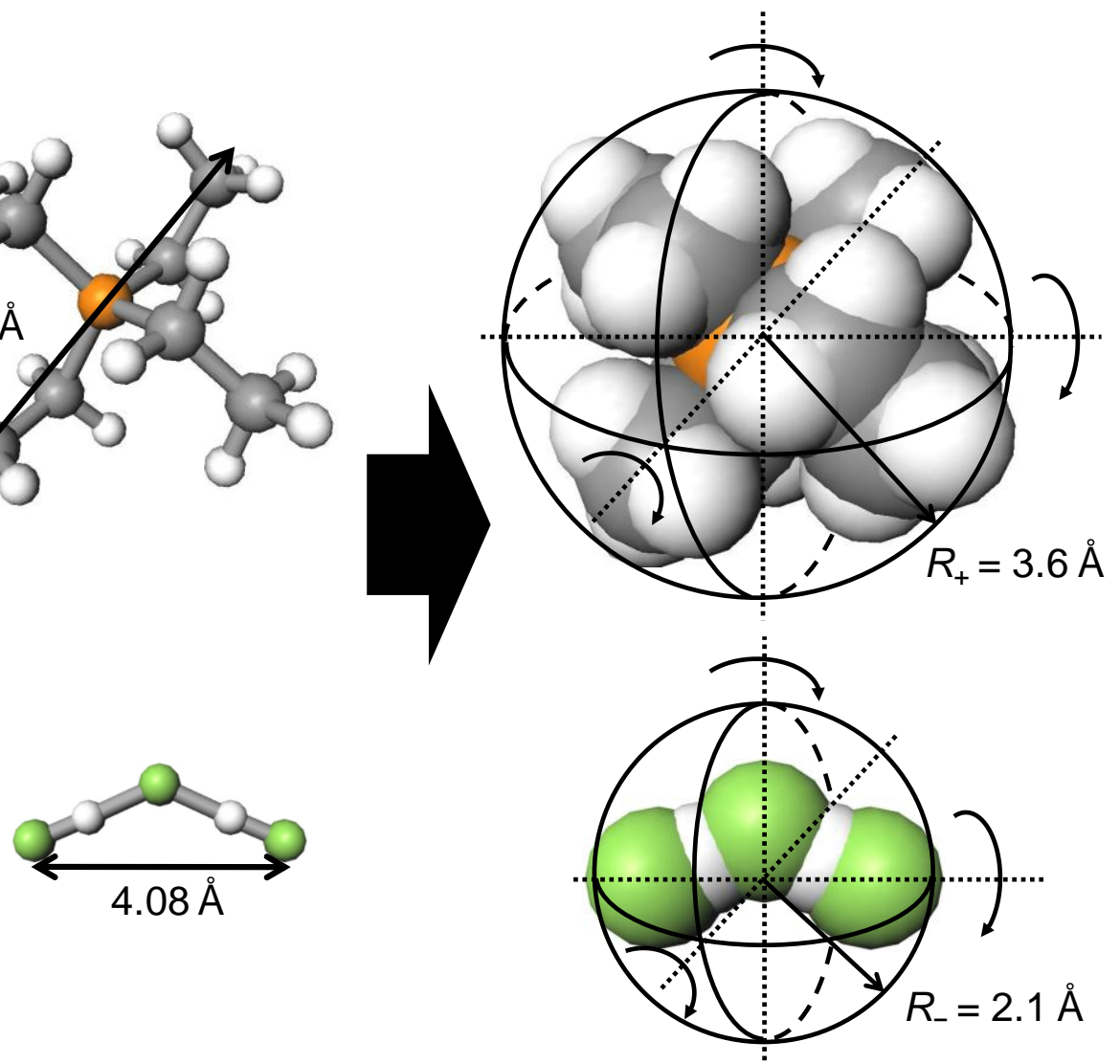

Figure 10. The optimized geometries and radii of spherical shapes for $\mathrm{P}_{2222}{ }^{+}$and $(\mathrm{FH})_{2} \mathrm{~F}^{-}$. 
(a) PC I

(b) PC II

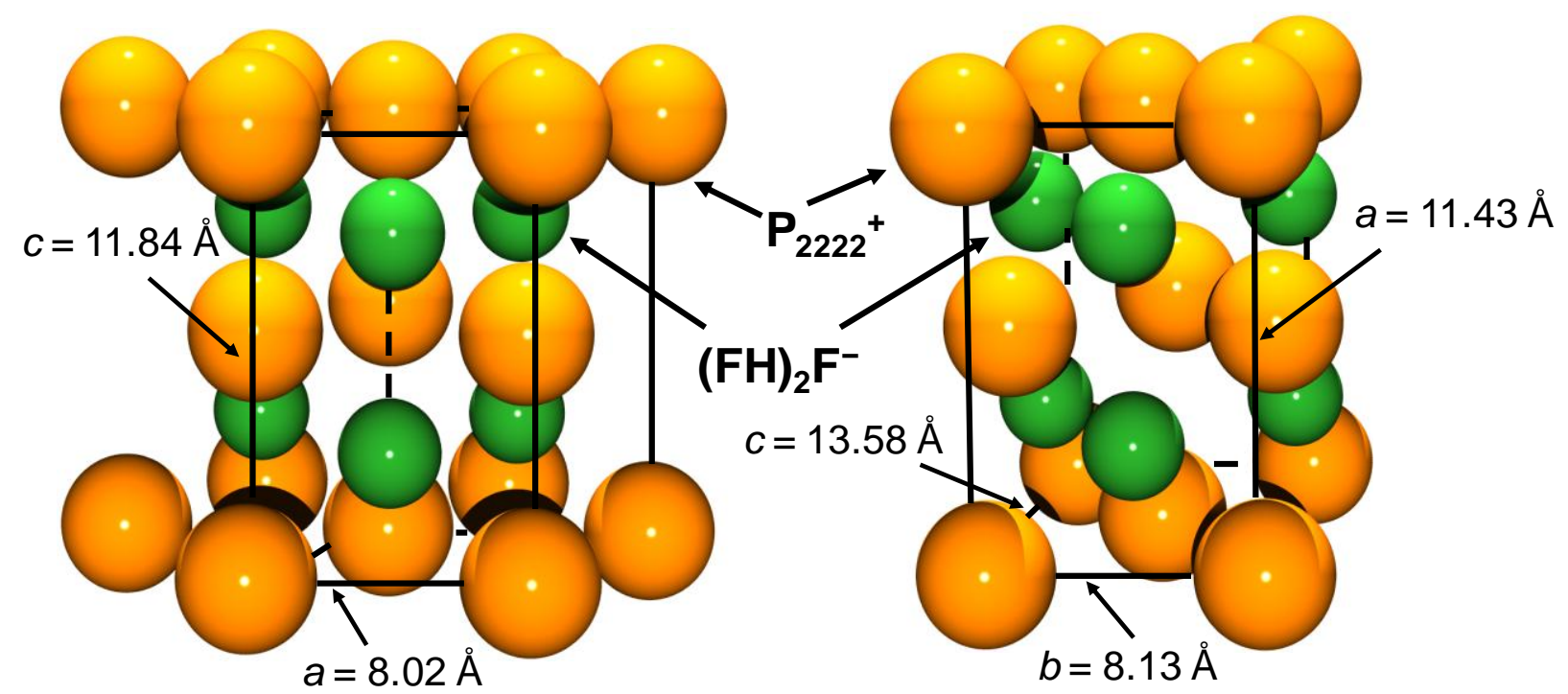

Figure 11. The unit cells of the (a) PC I and (b) PC II phases for $\mathrm{P}_{2222}(\mathrm{FH})_{2} \mathrm{~F}$. The crystal systems of PC I and PC II phases are hexagonal (inverse NiAs-type, $\left.P 6_{3} / m m c\right)$ and orthorhombic lattices (Pmma), respectively.

\section{Conclusions}

Fluorohydrogenate salts of quaternary phosphonium cations with short alkyl or methoxymethyl group were synthesized, and their physicochemical and structural properties were investigated. The $\mathrm{P}_{222 m}(\mathrm{FH})_{2.1} \mathrm{~F}(m=5,8$, and 1O1) salts are vacuum-stable liquids at room temperature with low viscosities and high ionic conductivities. Linear sweep voltammetry with a glassy carbon electrode shows that they have wide electrochemical windows $\left(4.9 \mathrm{~V}\right.$ for $\mathrm{P}_{222(1 \mathrm{O})}(\mathrm{FH})_{2.1} \mathrm{~F}$ and $5.8 \mathrm{~V}$ for $\mathrm{P}_{2225}(\mathrm{FH})_{2.1} \mathrm{~F}$ and $\left.\mathrm{P}_{2228}(\mathrm{FH})_{2.1} \mathrm{~F}\right)$. Thermogravimetry shows thermal stabilities of $\mathrm{P}_{2225}(\mathrm{FH})_{2.1} \mathrm{~F}$ and $\mathrm{P}_{2228}(\mathrm{FH})_{2.1} \mathrm{~F}$ are improved compared to $N$-heterocyclic ammonium-based fluorohydrogenate ILs although $\mathrm{P}_{222(101)}(\mathrm{FH})_{2.1} \mathrm{~F}$ exhibits a low thermal stability compared to other phosphonium 
fluorohydrogenate ILs. The salt, $\mathrm{P}_{2222}(\mathrm{FH})_{2} \mathrm{~F}$, exhibits two plastic crystal phases. The plastic crystal phase at the higher temperature exhibits the highest conductivity of $5 \mathrm{mS} \mathrm{cm}^{-1}$ at $50^{\circ} \mathrm{C}$ in the neat ionic plastic crystals and gives the first example of an inverse nickel arsenide-type structure. The ionic radii of $\mathrm{P}_{2222}{ }^{+}$and $(\mathrm{FH})_{2} \mathrm{~F}^{-}$were estimated from quantum mechanical calculations. The results showed that the simple radius-ratio rule (the ionic radius of anion / the ionic radius of cation) in determining the structure of an ionic compound can be also applied to plastic crystal structures. The other plastic crystal phase observed at lower temperature has an orthorhombic lattice.

\section{Acknowledgements}

This work was financially supported by Grant-in-Aid for Scientific Research for Priority Area “Science of Ionic Liquids” of MEXT and Grant-in-Aid for Scientific Research of JSPS, \#20246140.

\section{References}

1. J. S. Wilkes, Green Chem., 2002, 4, 73-80.

2. $\quad$ K. R. Seddon, J. Chem. Technol. Biotechnol., 1997, 68, 351-356.

3. P. Wasserscheid and W. Keim, Angew. Chem. Int. Ed., 2000, 39, 3772-3789.

4. R. Hagiwara and Y. Ito, J. Fluorine Chem., 2000, 105, 221-227.

5. T. Welton, Chem. Rev., 1999, 99, 2071-2083. 
6. H. Xue, R. Verma and J. M. Shreeve, J. Fluorine Chem., 2006, 127, 159-176.

7. R. Hagiwara and J. S. Lee, Electrochemistry, 2007, 75, 23-34.

8. H. Ohno, Electrochemical Aspects of Ionic Liquids, John Wiley and Sons, Inc., Hoboken, NJ, 2005.

9. R. D. Rogers and K. R. Seddon, Science, 2003, 302, 792-793.

10. P. Bonhote, A. P. Dias, N. Papageorgiou, K. Kalyanasundaram and M. Gratzel, Inorg. Chem., 1996, 35, 1168-1178.

11. H. Matsumoto, M. Yanagida, K. Tanimoto, M. Nomura, Y. Kitagawa and Y. Miyazaki, Chem. Lett., 2000, 922-923.

12. R. Hagiwara, T. Nohira, K. Matsumoto and Y. Tamba, Electrochem. Solid State Lett., 2005, 8, A231-A233.

13. D. R. McFarlane, J. Sun, J. Golding, P. Meakin and M. Forsyth, Electrochim. Acta, 2000, 45, 1271-1278.

14. C. Nanjundiah, S. F. McDevitt and V. R. Koch, J. Electrochem. Soc., 1997, 144, 3392-3397.

15. C. J. Bradaric, A. Downard, C. Kennedy, A. J. Robertson and Y. H. Zhou, Green Chem., 2003, 5, $143-152$.

16. R. E. Del Sesto, C. Corley, A. Robertson and J. S. Wilkes, J. Organomet. Chem., 2005, 690, 2536-2542.

17. J. Kagimoto, K. Fukumoto and H. Ohno, Chem. Commun., 2006, 2254-2256.

18. K. Tsunashima and M. Sugiya, Electrochem. Comm., 2007, 9, 2353-2358. 
19. R. Hagiwara, K. Matsumoto, Y. Nakamori, T. Tsuda, Y. Ito, H. Matsumoto and K. Momota, J.

Electrochem. Soc., 2003, 150, D195-D199.

20. K. Binnemans, Chem. Rev., 2005, 105, 4148-4204.

21. M. Yoshio, T. Kagata, K. Hoshino, T. Mukai, H. Ohno and T. Kato, J. Am. Chem. Soc., 2006, 128, 5570-5577.

22. A. E. Bradley, C. Hardacre, J. D. Holbrey, S. Johnston, S. E. J. McMath and M. Nieuwenhuyzen, Chem. Mater., 2002, 14, 629-635.

23. H. Shimura, M. Yoshio, K. Hoshino, T. Mukai, H. Ohno and T. Kato, J. Am. Chem. Soc., 2008, 130, 1759-1765.

24. T. Mukai, M. Yoshio, T. Kato, M. Yoshizawa and H. Ohno, Chem. Commun., 2005, 1333-1335.

25. C. J. Bowlas, D. W. Bruce and K. R. Seddon, Chem. Commun., 1996, 1625-1626.

26. N. Yamanaka, R. Kawano, W. Kubo, T. Kitamura, Y. Wada, M. Watanabe and S. Yanagida, Chem. Commun., 2005, 740-742.

27. F. Xu, K. Matsumoto and R. Hagiwara, Chem.-Eur. J., 2010, 16, 12970-12976.

28. Z. B. Zhou, H. Matsumoto and K. Tatsumi, Chem.-Eur. J., 2005, 11, 752-766.

29. D. R. MacFarlane, P. Meakin, J. Sun, N. Amini and M. Forsyth, J. Phys. Chem. B, 1999, 103, 4164-4170.

30. D. R. MacFarlane and M. Forsyth, Advanced Materials, 2001, 13, 957-966.

31. D. R. MacFarlane, J. H. Huang and M. Forsyth, Nature, 1999, 402, 792-794.

32. M. Forsyth, J. Huang and D. R. MacFarlane, J. Mater. Chem., 2000, 10, 2259-2265. 
33. Y. Abu-Lebdeh, P. J. Alarco and M. Armand, Angew. Chem. Int. Ed., 2003, 42, 4499-4501.

34. Y. Abu-Lebdeh, A. Abouimrane, P. J. Alarco, A. Hammami, L. Ionescu-Vasii and M. Armand, Electrochem. Comm., 2004, 6, 432-434.

35. P. J. Alarco, Y. Abu-Lebdeh, N. Ravet and M. Armand, Solid State Ionics, 2004, 172, 53-56.

36. Z. B. Zhou and H. Matsumoto, Electrochem. Comm., 2007, 9, 1017-1022.

37. S. Long, D. R. MacFarlane and M. Forsyth, Solid State Ionics, 2003, 161, 105-112.

38. S. Long, D. R. MacFarlane and M. Forsyth, Solid State Ionics, 2004, 175, 733-738.

39. P. J. Alarco, Y. Abu-Lebdeh, A. Abouimrane and M. Armand, Nature Materials, 2004, 3, 476481.

40. P. Wang, Q. Dai, S. M. Zakeeruddin, M. Forsyth, D. R. MacFarlane and M. Gratzel, J. Am. Chem. Soc., 2004, 126, 13590-13591.

41. Q. Dai, D. R. MacFarlane, P. C. Howlett and M. Forsyth, Angew. Chem. Int. Ed., 2005, 44, 313316.

42. M. Patel, K. G. Chandrappa and A. J. Bhattacharyya, Electrochim. Acta, 2008, 54, 209-215.

43. M. Patel and A. J. Bhattacharyya, Electrochem. Comm., 2008, 10, 1912-1915.

44. A. J. Bhattacharyya, M. Patel and S. K. Das, Monatshefte Fur Chemie, 2009, 140, 1001-1010.

45. S. Das, S. J. Prathapa, P. V. Menezes, T. N. G. Row and A. J. Bhattacharyya, J. Phys. Chem. B, 2009, 113, 5025-5031.

46. M. Patel, P. V. Menezes and A. J. Bhattacharyya, J. Phys. Chem. B, 2010, 114, 5233-5240.

47. R. Hagiwara, T. Hirashige, T. Tsuda and Y. Ito, J. Fluorine Chem., 1999, 99, 1-3. 
48. R. Hagiwara, T. Hirashige, T. Tsuda and Y. Ito, J. Electrochem. Soc., 2002, 149, D1-D6.

49. R. Hagiwara, Y. Nakamori, K. Matsumoto and Y. Ito, J. Phys. Chem. B, 2005, 109, 5445-5449.

50. K. Matsumoto, R. Hagiwara and Y. Ito, Electrochem. Solid State Lett., 2004, 7, E41-E44.

51. K. Matsumoto and R. Hagiwara, Electrochemistry, 2005, 73, 730-732.

52. M. Yamagata, S. Konno, K. Matsumoto and R. Hagiwara, Electrochem. Solid State Lett., 2009, 12, F9-F12.

53. S. Kanematsu, K. Matsumoto and R. Hagiwara, Electrochem. Comm., 2009, 11, 1312-1315.

54. T. Enomoto, Y. Nakamori, K. Matsumoto and R. Hagiwara, J. Phys. Chem. C, 2011, 115, 43244332.

55. M. Ue, M. Takeda, A. Toriumi, A. Kominato, R. Hagiwara and Y. Ito, J. Electrochem. Soc., 2003, 150, A499-A502.

56. A. Senda, K. Matsumoto, T. Nohira and R. Hagiwara, J. Power Sources, 2010, 195, 4414-4417.

57. D. Peters and R. Miethchen, J. Fluorine Chem., 1996, 79, 161-165.

58. RAPID XRD, version 2.3.3, Rigaku Corporation, Tokyo, Japan. 1999

59. A. Boultif and D. Louer, J. Appl. Crystallogr., 2004, 37, 724-731.

60. M. J. Frisch, G. W. Trucks, H. B. Schlegel, G. E. Scuseria, M. A. Robb, J. R. Cheeseman, J. J. A. Montgomery, T. Vreven, K. N. Kudin, J. C. Burant, J. M. Millam, S. S. Iyengar, J. Tomasi, V. Barone, B. Mennucci, M. Cossi, G. Scalmani, N. Rega, G. A. Petersson, H. Nakatsuji, M. Hada, M. Ehara, K. Toyota, R. Fukuda, J. Hasegawa, M. Ishida, T. Nakajima, Y. Honda, O. Kitao, H. Nakai, M. Klene, X. Li, J. E. Knox, H. P. Hratchian, J. B. Cross, V. Bakken, C. Adamo, J. 
Jaramillo, R. Gomperts, R. E. Stratmann, O. Yazyev, A. J. Austin, R. Cammi, C. Pomelli, J. W.

Ochterski, P. Y. Ayala, K. Morokuma, G. A. Voth, P. Salvador, J. J. Dannenberg, V. G.

Zakrzewski, S. Dapprich, A. D. Daniels, M. C. Strain, O. Farkas, D. K. Malick, A. D. Rabuck, K.

Raghavachari, J. B. Foresman, J. V. O. Q. Cui, A. G. Baboul, S. Clifford, J. Cioslowski, B. B.

Stefanov, G. Liu, A. Liashenko, P. Piskorz, I. Komaromi, R. L. Martin, D. J. Fox, T. Keith, M. A.

Al-Laham, C. Y. Peng, A. Nanayakkara, M. Challacombe, P. M. W. Gill, B. Johnson, W. Chen,

M. W. Wong, C. Gonzalez and J. A. Pople, Gaussian 03, Revision E.01, Gaussian, Inc.,

Wallingford CT. 2004

61. R. V. Winsor and G. H. Cady, J. Am. Chem. Soc., 1948, 70, 1500-1502.

62. G. H. Cady, J. Am. Chem. Soc., 1934, 56, 1431-1434.

63. S. Seki, Y. Umebayashi, S. Tsuzuki, K. Hayamizu, Y. Kobayashi, Y. Ohno, T. Kobayashi, Y. Mita, H. Miyashiro, N. Terada and S. I. Ishiguro, Chem. Commun., 2008, 5541-5543.

64. K. Tsunashima and M. Sugiya, Electrochemistry, 2007, 75, 734-736.

65. J. M. Slattery, C. Daguenet, P. J. Dyson, T. J. S. Schubert and I. Krossing, Angew. Chem. Int. Ed., 2007, 46, 5384-5388.

66. S. Q. Chen, T. Hatakeyama, T. Fukuhara, S. Hara and N. Yoneda, Electrochim. Acta, 1997, 42, 1951-1960.

67. H. Groult, C. Simon, A. Mantoux, F. Lantelme and P. Turq, Fluorinated Materials for Energy Conversion, Elsevier, Oxford, 2005.

68. F. Lantelme and H. Groult, J. Electrochem. Soc., 2004, 151, D121-D126. 
69. J. Timmermans, J. Phys. Chem. Solids, 1961, 18, 1-8.

70. C. M. Forsyth, D. R. MacFarlane, J. J. Golding, J. Huang, J. Sun and M. Forsyth, Chem. Mater., 2002, 14, 2103-2108.

71. W. A. Henderson, V. G. Young, S. Passerini, P. C. Trulove and H. C. De Long, Chem. Mater., 2006, 18, 934-938.

72. W. A. Henderson, M. Herstedt, V. G. Young, S. Passerini, H. C. De Long and P. C. Trulove, Inorg. Chem., 2006, 45, 1412-1414.

73. W. A. Henderson, V. G. Young, W. Pearson, S. Passerini, H. C. De Long and P. C. Trulove, Journal of Physics-Condensed Matter, 2006, 18, 10377-10390.

74. R. Asayama, J. Kawamura and T. Hattori, Chem. Phys. Lett., 2005, 414, 87-91.

75. K. Kuchitsu, H. Ono, S. Ishimaru, R. Ikeda and H. Ishida, Phys. Chem. Chem. Phys., 2000, 2, 3883-3885 and references therein.

76. P. Atkins, T. Overton, J. Rourke, M. Weller and F. Armstrong, Shriver \& Atkins Inorganic Chemistry, 6th edn., Oxford University Press, Oxford OX2 6DP, 2006.

77. K. O. Christe, W. W. Wilson, R. D. Wilson, R. Bau and J. A. Feng, J. Am. Chem. Soc., 1990, 112, 7619-7625. 